\title{
Menderes Masifi'nde Açılmış Açık Ocak Albit Madenindeki Bir Duraysızlığın Nedenlerinin Araştırılması ve Robotic Total Station Cihazı Kullanılarak Yenilme Öncesinde Şev Hareketlerinin İzlenmesi
}

Investigation of the Causes of an Instability in an Albite Mine Opened in Menderes Massif and Monitoring Slope Movements Before the Failure Employing Robotic Total Station Equipment

\author{
Saffet Deniz KARAGÖZ ${ }^{1}$ (D), Cem KINCAL ${ }^{2}$ iD ve M. Yalçın KOCA ${ }^{2}$ D
}

${ }^{1}$ Dokuz Eylül Üniversitesi, Fen Bilimleri Enstitüsü Tınaztepe, Buca/İzmir

${ }^{2}$ Dokuz Eylül Üniversitesi, Mühendislik Fakültesi Jeoloji Mühendisliği Bölümü Tınaztepe, Buca/İzmir.

ÖZ

19.12.2018 tarihinde Menderes Masifi içinde, ayrışmış gnayslarda yer alan bir açık ocak madeninde büyük ölçekli bir heyelan meydana gelmiştir. Hemen hemen şev yüzeyine paralel uzanan bir yenilme yüzeyi oldukça sığ bir derinlikte gelişmiştir (Maksimum derinlik: $17 \mathrm{~m}$ ). Duraysızlığın geliştiği şevin genel açısı $25^{\circ}$ ve genel şev yüksekliği ise 80 m'dir (Kotlar: $490 \mathrm{~m}-410 \mathrm{~m}$ ). Kayan malzeme miktarı ise yaklaşık $700 \times 10^{3} \mathrm{~m}^{3 \prime}$ tür. Açık ocaktaki kaya şevlerinde duraysızlık tümüyle gerçekleşmeden önce kayda değer deformasyonlar meydana gelmiş̧ir. Heyelan oluşumu öncesindeki söz konusu şev hareketlerinin zamana bağlı olarak (2017-2018 yılları arası, 750 gün) izlenmesi ve duraysızlığın nedenlerinin araştırılması bu çalışmada amaçlanmıştır. Hareket izleme çalışmaları sırasında günlük ve saatlik yağış miktarları da ölçülmüş ve kaydedilmiştir. Jeolojik yapı ile duraysızlığın mekanizması arasındaki ilişkiyi belirlemek için şev hareketi ölçüm verileri eş zamanlı yağış verileriyle birlikte "GeoMoS" bilgisayar programı kullanılarak değerlendirilmiştir. Önceden cevherin tavan bloğunda küçük ölçekli bazı şev duraysızlıkları not edilmiştir. Diğer taraftan, gelişmiş yenilme yüzeyi boyunca, yeraltı suyu basınç değişimlerinin tetiklediği daha büyük yer değiştirmeleri kapsayan yoğun yağışlı dönemler, cevherin tavan bloğunda meydana gelen büyük ölçekli yenilmeyi ilerletmiştir. Kurak dönemlerde, şev hareketlerinin hızı ortalama 3.5 mm/gün'dür. 04.12.2018 tarihinde gerçekleştirilen üçüncü dekapaj çalışması nedeniyle açık ocakta şev hareketleri bir miktar ivmelenmiştir. Şev topuğunda gerçekleştirilen kontrolsüz kazıya kadar (14.12.2018), şevin toplam bileşke yer değiştirme miktarı $100 \mathrm{~cm}$ artmıştır ve bu dönemde hareketlerin ortalama hızı $10 \mathrm{~cm} /$ gün olarak hesaplanmıştır. Son olarak, topuk kazısından duraysızlığın geliştiği tarihe kadar (19.12.2018), yoğun yağışların eşlik ettiği hareketin miktarı $160 \mathrm{~cm} /$ gün olarak gerçekleşmiştir. Hareket izleme ölçümlerine göre şevin toplam bileşke yer değiştirmesi $10.5 \mathrm{~m}$ seviyesinde gerçekleşmiştir. Ayrıca, duraysızlığın gelişimindeki farklı safhalarını tanımlamaya yönelik olarak bazı göstergeler de belirlenmiştir. En önemli göstergeler yer değiştirmeler, topuktaki kabarmalar ve şev topuğuna yakın yüksekliklerde meydana gelen makaslama deformasyon birikimleridir.

Anahtar kelimeler: Heyelan, Açık ocak, Şev hareketleri, Yağışs, İzleme 
Karagöz, Kıncal, Koca

\section{ABSTRACT}

A large-scale landslide in an open pit mine located in weathered gneiss unit in Menderes Massif occurred on 19.12.2018. The open pit mine failure occurred on a fairly shallow failure surface (maximum depth: $17 \mathrm{~m}$ ), running almost parallel to the slope face. At that time, the overall slope height was 80 meters (elevations: $490 \mathrm{~m}-410 \mathrm{~m}$ ) and overall slope angle $25^{\circ}$. The failure involved around $700 \times 10^{3} \mathrm{~m}^{3}$ of rock. Significant displacements in rock slopes in the pit occurred before the failure surfaces had fully developed. This study aims to investigate the causes of the landslide and to monitor slope movements in the landslide area before the failure. While monitoring the movement (between 2017 and 2018, 750 days), amount of rainfall per day and per hour was also measured and recorded. The amount of rainfall has been evaluated in conjunction with the time-dependent slope movement data (timedependent surface displacement measurements) by using the software "GeoMoS" to determine the relationship between the geological structure and the landslide mechanism. Some small scale instabilities have been observed in the hanging wall beforehand. The large scale failure of the hanging wall, however, has progressed during the periods of heavy rainfall, suggesting that the variations in groundwater pressures triggered larger displacements along the developed failure surface. During dry weather, the slope moved at a rate of about $3.5 \mathrm{~mm} /$ day. Slope movement slightly accelerated in open pit due to the work of third overburden removal at the date of 04.12.2018. Until the uncontrolled overburden removal at the slope toe (14.12.2018), the amount of the total resultant displacement of the slope increased up to $100 \mathrm{~cm}$ and the rate of slope movement was calculated as $10 \mathrm{~cm} /$ day. Finally, from the uncontrolled excavation of the slope toe (14.12.2018) to 19.12.2018 (when the landslide occurred) the movement accompanied by the intense rainfall, occurred as $160 \mathrm{~cm} /$ day. Total resulting displacement of the slope at the end of this measurement campaign was at the amount of $10.5 \mathrm{~m}$. In addition, some indicators before the failure were determined to define the different stages of the landslide. It was also determined that the most important indicators are the displacements, heaves, and shear-strain accumulation at an elevation near the slope toe.

Keywords: Landslide, Open pit, Slope movements, Rainfall, Monitoring

\section{GİRIS}

İnceleme alanı, Menderes Masifi'nin Çine As masifine ait gözlü gnayslar içerisinde açılmış bir açık maden ocağıdır. Açık ocak, Karadere makaslama zonu boyunca oluşmuş olan albit cevherinde açılmıştır (Karagöz ve Koca, 2016; Koca, vd. 2010; Koca vd., 2012; Tanyaş ve Ulusay, 2013; Kıncal, 2014; Kadakçı ve Koca, 2014).

Heyelan öncesine ait 2012-2014 yıllar1 arasındaki 700 günlük dönemde, şev hareketlerini izleme sonuçlarını mühendislik jeolojisi açısından değerlendirmesi Karagöz ve Koca (2016) tarafından yapılmıştır. Bu çalışmada ise 10.02.2017-19.12.2018 tarihleri arasındaki heyelan öncesine ait son 750 günlük dönem aynı amaçlar doğrultusunda "Robotic Total Station" cihazıyla alınan ölçümler kullanılarak değerlendirilmiştir. 19.12.2018'de açık ocağın tavan bloğunda heyelan meydana gelmiş ve sekiz şev kademesi etkilenmiştir (Şekil 1). $\mathrm{Bu}$ araştırmanın amac1, 19.12.2018 tarihinde oluşan heyelanın (Şekil 1) öncesindeki gelişim sürecini, oluşum nedenlerini ve sonucunu deformasyon ölçümleri, farklı zamanlarda alınmış insansız hava aracı görüntüleri, çatlak gelişimlerinin haritalanması ve yağış verileriyle birlikte incelemek, hassas ölçümlere dayanan verilerle saha gözlemlerini karşılaştırmak, heyelan kaymasının başlangıç, gelişme ve oluş mekanizmasını deformasyonları dikkate alarak modellemektir. Bu incelemelerde çatlak ölçümleri, deformasyon ölçümleri ve yağış verilerinin yanısıra aynı hat üzerinde farklı tarihlerde alınmış dört topoğrafik kesitin çakıştırılmasından da yararlanılmıştır. Heyelanın değişik aşamalarında, farklı tarihlerde alınmış insansız hava aracı görüntülerinden heyelanın belirteçleri belgelenerek dökümantasyon 
sağlanmıştır. Çalışmanın diğer bir amacı, Karagöz ve Koca (2016)'da potansiyel heyelanın öngörülen etki alanıyla, heyelan gerçekleştikten sonra oluşan etki alanını karşılaştırmaktır.

Heyelan 19.12.2018 tarihinde meydana gelmiştir. Kayma öncesindeki son beş günde şevde çok yüksek deformasyonlar kaydedilmiştir. Önceden yağış ve deformasyon rampalarında (yağış ve deformasyonların artış gösterdiği zaman aralıkları) meydana gelen olumsuzluklar belli dönemlerde gerçekleştirilen inceltme kazıları ve drenajla üstesinden gelinmiştir. Her defasında heyelanın regresif aşamadan (geriye dönük yenilme aşaması) progresif aşamaya (ileriye dönük yenilme aşaması) geçmesi alınan önlemlerle bertaraf edilmiştir. Karagöz ve Koca (2016) tarafindan yayımlanan makale Aydın/Karpuzlu'daki açık ocak albit madeninin GD'da yeralan potansiyel heyelan sahasindaki şev hereketlerinin izlenmesi ve nedenlerinin araştırılmasıyla ilgilidir.

Karagöz ve Koca (2016) tarafindan hazırlanan makalede iki ilişki ayrıntılı olarak incelenmiştir. Birincisi; heyelan izleme istasyonlarındaki kümülatif yer değiştirme hareketlerinin yönlem ve dalımıyla, gnayslar içinde mevcut foliasyon düzlemlerinin eğim yönü-eğim açısı değerleri arasındaki ilișkidir. İkincisi ise, önceki topoğrafyada mevcut dere yataklarının akış yönleriyle bu yatakların yakınında yer alan foliasyonların eğim yönleri arasındaki ilişki belgelenmiştir. Makalede, gömülü dere yatakları boyunca sızan suların geniş foliasyon yüzeyleri boyunca heyelan sahasına taşındığı belirtilmiştir. Ayrıca açık ocaktaki basamak şevlerini kesen foliasyonlar boyunca nemli zonların varlığ 1 ve bu düzlemler boyunca birkaç basamağı etkileyen düzlemsel ve kama tipi kaymaların geliştiğine vurgu yapılmıştır (Regresif yenilmeler). Makalede heyelanın etki sahasının KD-GB yönündeki uzunluğu yaklaşık $300 \mathrm{~m}$, KB-GD yönündeki boyu ise (heyelanın hareket yönünde) yaklaşık $230 \mathrm{~m}$ olarak tahmin edilmiştir (Şekil 2). Coğrafi Bilgi Sistemleri (CBS) kullanılarak eklemeli hareket vektörlerinin yönlemleri, bileşke yer değiştirme miktarları, eski dere yatakları ve güncel topoğrafya gibi veri katmanları çakıştırılmıştır. Elde edilen tematik haritada bileşke yer değiştirme miktarları zonlanarak potansiyel heyelan sahasında deformasyonların en yüksek ve en düşük olduğu bölgeler ortaya çıkartılmıştır (Karagöz ve Koca, 2016). Heyelanın olası kayma yönünün $310^{\circ}$ (K50B) ile ocak tabanına doğru olduğu belirtilmiştir.

Açık ocaktaki olağan dişı değişimler, basamaklarda veya şev gerisinde meydana gelen gerilme çatlakları, kabarmalar şeklinde genellikle şev topuğunda meydana gelen küçük kubbemsi yükselmeler ve kaya ortamda süreksizliklerde meydana gelen açılmaları kapsar (Call ve Savely, 1991; Bell ve Glade, 2004). Açık ocaktaki şev yenilmelerinin mekanizmaları tam olarak anlaşılmışsa, açık ocaklarda kısa zaman aralıklarıyla güvenli bir şekilde cevher üretimine devam edilmektedir (Wang vd., 2010; Allasia vd., 2013). Ancak bu durum, uzmanlarca yapilan önerilere tam uyum göstermekle mümkün olmaktadır. Açık ocakta birden fazla olumsuz etkinin (yanlış kazı, uzun süren aşırı yağışlar ve sismik etki gibi) aynı zaman diliminde etkinleşmesi de kütle hareketlerinin meydana gelme potansiyelini arttırmaktadır. 
44 Menderes Masifi'nde Açılmış Açık Ocak Albit Madenindeki Bir Duraysızlı̆ı̆n Nedenlerinin Araş̧ıııIması ve Robotic Total Station Cihazı Kullannlarak Yenilme Öncesinde Şev Hareketlerinin Izlenmesi

Karagöz, Kıncal, Koca
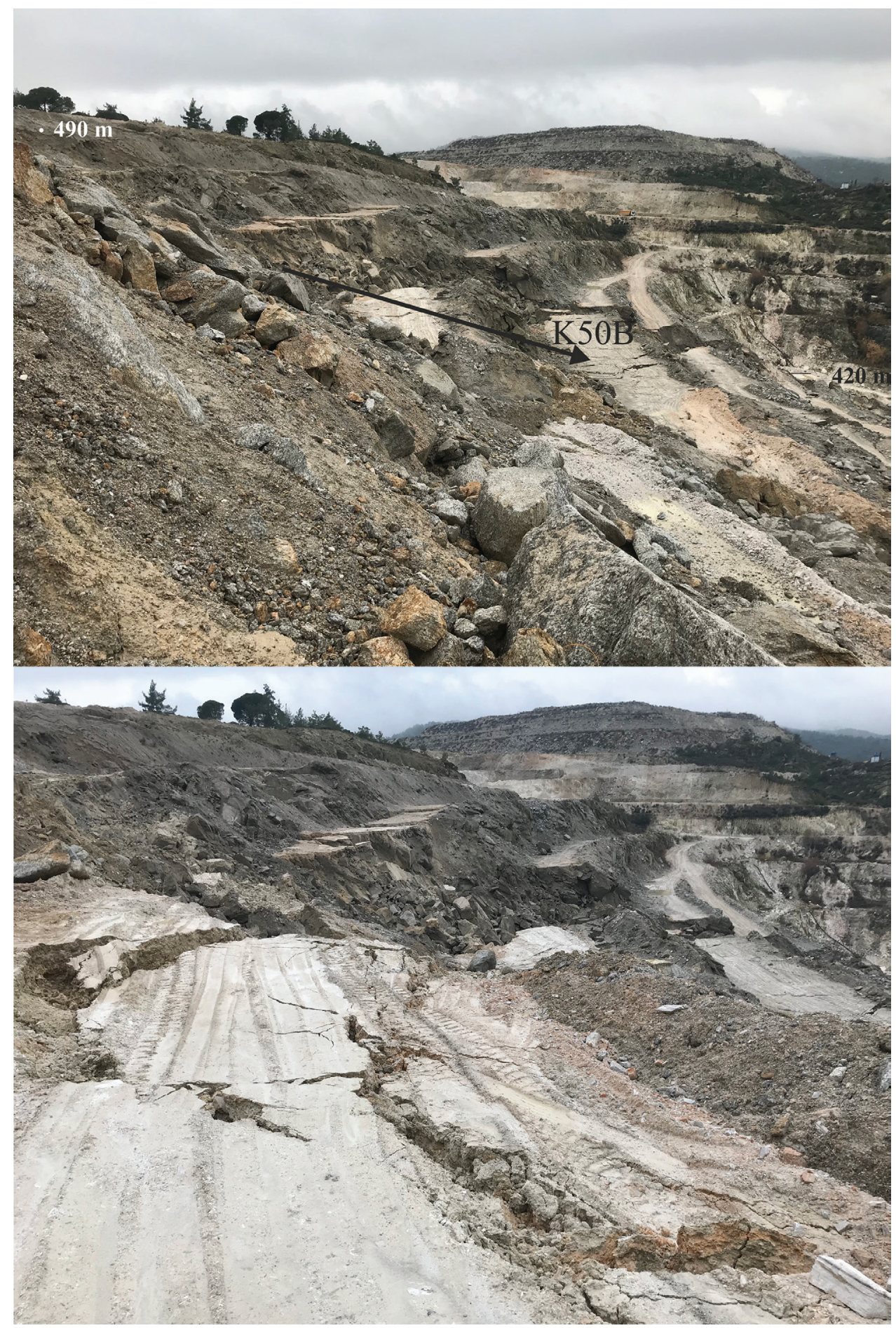

Şekil 1. Yenilme sonrası heyelan topoğrafyası (Foto:19.12.2018, sabah-7.30).

Figure 1. Landslide topography after the failure (Photo: 19.12.2018, 7.30 am). 


\section{JEOLOJI}

Açık ocak madeni Menderes Masifi'nin Çine As masifi içerisinde, çekirdek serisi olarak adlandırılan gözlü gnayslar içerisinde yer almaktadır. Açık ocağ 1 boydan boya kesen Karadere makaslama zonu boyunca feldispat (albit) cevheri zenginleşmiştir. Ayrıca zon boyunca mika ve kuvarsit damarları da gözlenmiştir (Şekil 2). Açık ocak işletmesi K25D yönünde uzanır ve $450 \mathrm{~m}$ uzunluğa ve $25-55 \mathrm{~m}$ genişliğe sahiptir. Gözlü gnayslar foliasyonlu ve çatlaklı bir yapı gösterirler (Koca vd., 2010; Koca vd., 2012; Tanyaş ve Ulusay, 2013; Kadakçı, 2014). Heyelan potansiyeline sahip saha içerisinde foliasyonların konumları Şekil 2'deki kontur diyagramlarında gösterilmiştir. Buna göre; foliasyonların eğim açıları $26^{\circ}$ $40^{\circ}$ arasında değişirken doğrultuları genelde $\mathrm{K}-\mathrm{G}$ veya KB-GD' dur. Foliasyonlanın eğim yönleri ise $210^{\circ}-347^{\circ}$ arasındadır. Foliasyon düzlemlerinin eğim yönleri ocağın GD'da yamaç dışına eğimliyken, KB'da yamaç içine eğimlidir (Şekil 2). Çatlak setlerinin konumları ise; Set-1: 80-90/325-340, 80-90/290-320, Set2: 70-85/190-210, 82-90/40-70'dur. Aç1k ocak işletmesinde yaklaşık düşey konumlu çatlakların (82-90/40-70) foliasyon düzlemlerini kestiği ve blok oluşumuna neden olduğu belirlenmiştir. Foliasyonlar şev kademelerini kesmekte, ancak genel şevi kesmemektedir. Açık ocak şevlerinde blok oluşumunu tamamlayan diğer bir çatlak seti ise $325-340 / 80^{\circ}-90^{\circ}$ konumludur (Şekil 2).

\section{YÖNTEMLER}

Açık ocaktaki tüm deformasyon ölçümleri (yer değiştirme ölçümleri) 2017 yılının başından itibaren (10.02.2017) 7/24 LEICA tm50 marka "Robotic Total Station" cihazıyla yapılmaktadır. İnceleme alanında 2017 y1lı öncesinde şev hareketleri "Leica GS15" GPS aracılığıyla yapılmıştır. Robotic Total Station ile alınan ölçümler "Leica GeoMoS" yazılımı yardımıyla işlenmekte ve veriler grafik olarak elde edilebilmektedir. Söz konusu cihaz heyelanlı sahaya yerleştirilmiş prizmalar (Target prism) ve bu prizmaları görecek şekilde konumlandırılmış bir ana istasyondan (Base station) oluşur (Şekil 3). Robotic Total Station (GRS - Geotechnical E. 541 - 7394/7306) ile sürekli izleme sisteminin yerleştirileceği yer; sahaya hakim olan ve şehir şebeke elektriği ve iletişim altyapısından yararlanabilecek bir seyir terasıdır (Base station), (Call, 1982; Palozzo vd., 2006; Afeni vd., 2013). Sahanın konumu ve mesafeler tam bu çalışmalar için uygun olmalıdır. Şekil 4'te deformasyon ölçüm noktalarının lokasyonları ayrıntılı olarak gösterilmiştir. Sahada cevher üretimine yönelik patlatmalardan ana istasyonun etkilenmemesi için cihaz üzerine bir eğim sensörü tesis edilmiştir. $\mathrm{Bu}$ bağımsız bir yöntemle kaidenin kontrolünü sağlamaktadır. Bu tür çalışmalarda kabin yerinin seçimi kadar, kabin ile sunucu (server) arasındaki iletişimin sürekliliğinin sağlanması da önemlidir. 


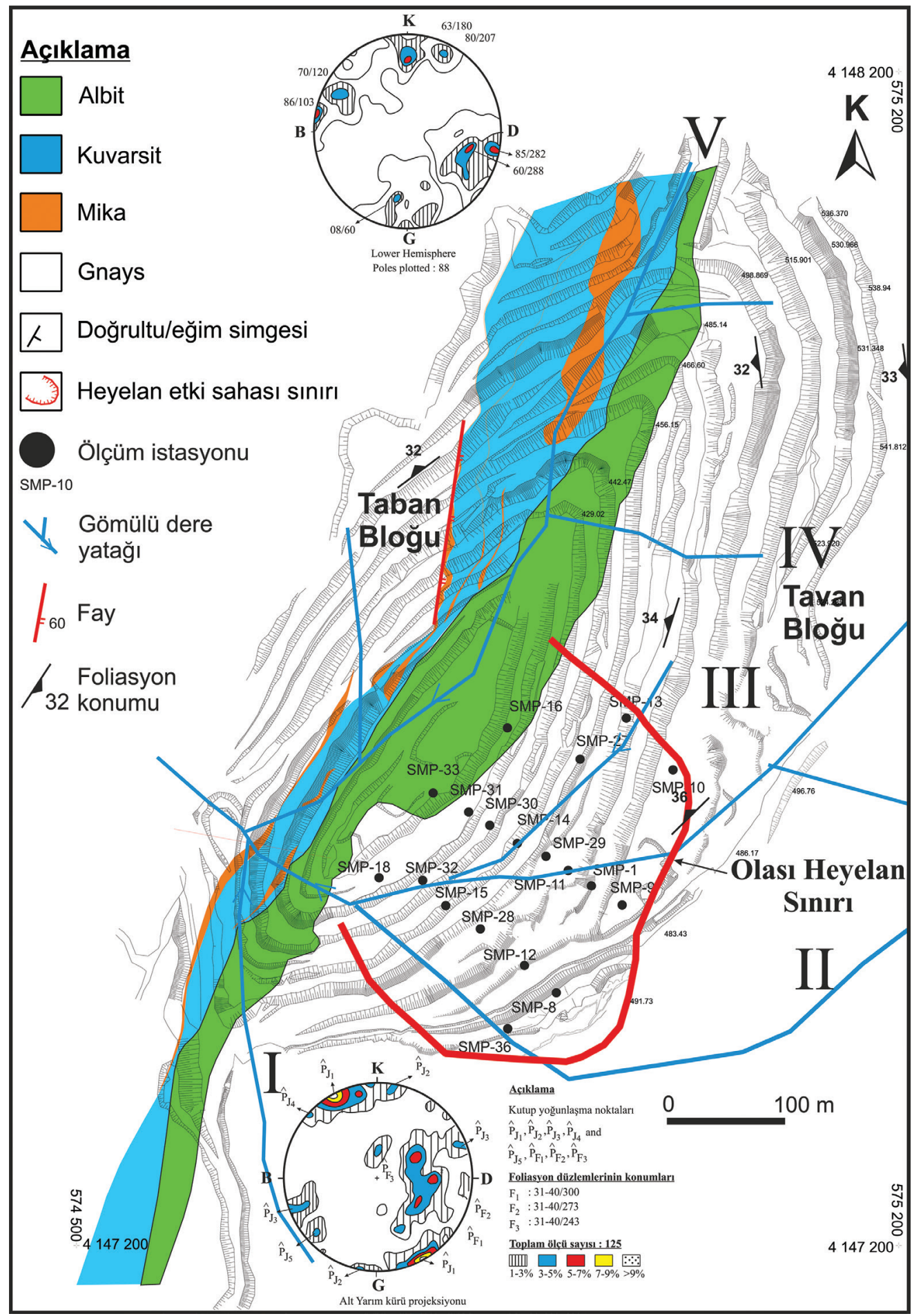

Şekil 2. Açık ocak işletme sahasının mühendislik jeolojisi haritası (Karagöz ve Koca, 2016).

Figure 2. Engineering geological map of the open-pit mine site (Karagöz and Koca, 2016). 


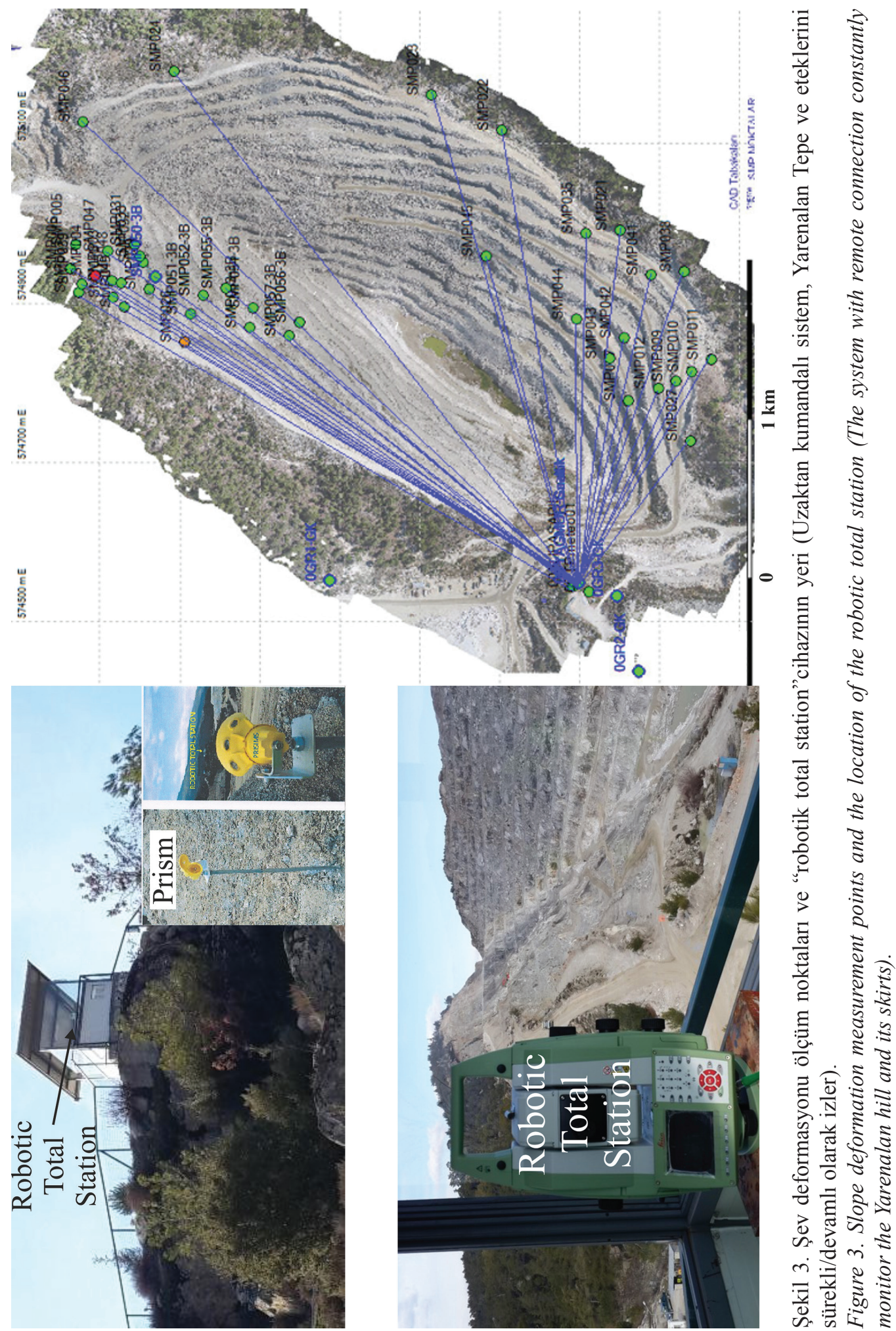




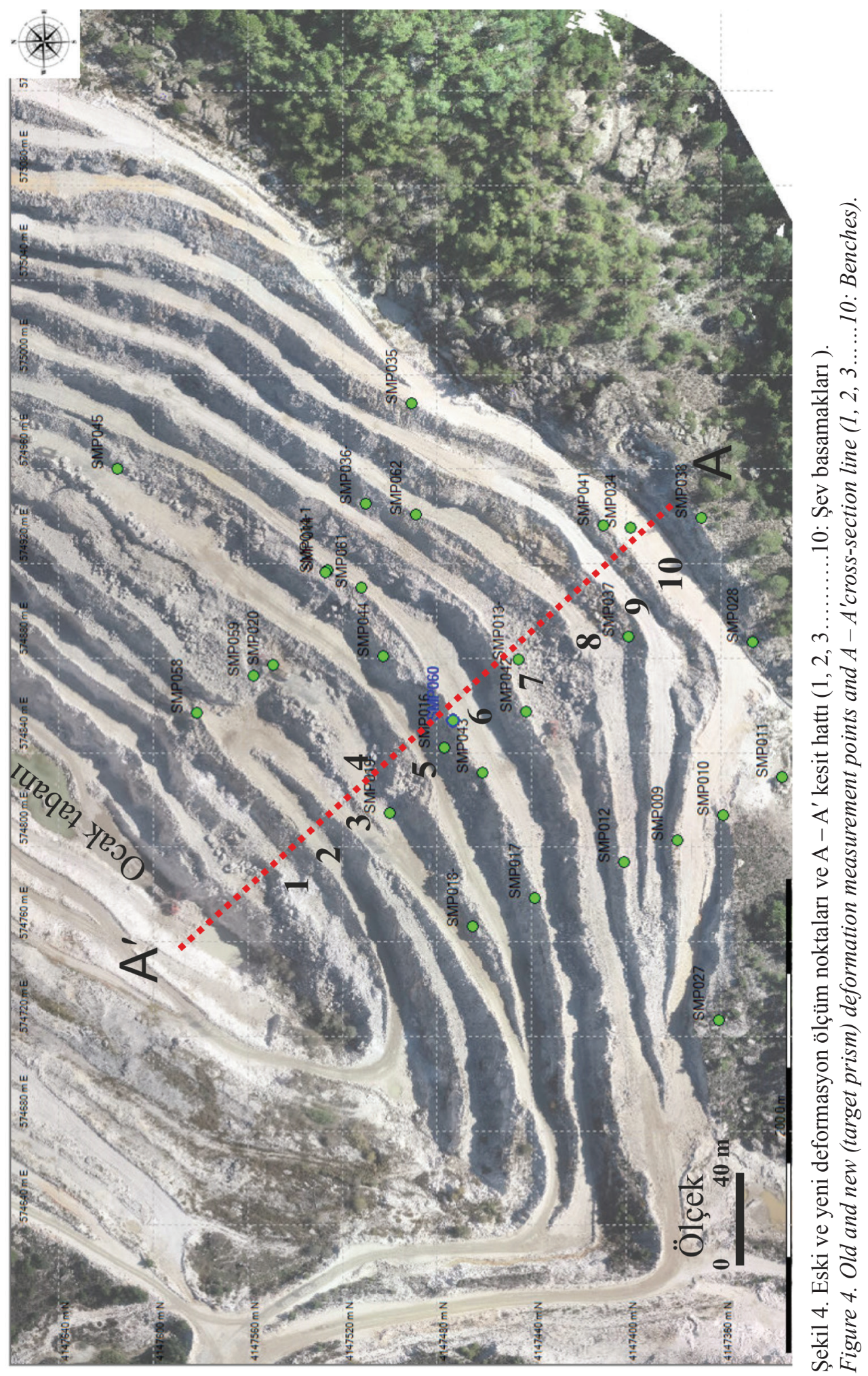


Sunucu (server) sahada bulunan büroya kurulmuştur. Böylece, total station ile kabin arasında kablolu bir iletişim sağlanmıştır. "GeoMoS" oldukça esnek otomatik bir deformasyon gözlem sistemi sunar. GeoMoS Monitör ile sahadaki tüm gerçek zamanlı sensörlerin yönetimi sağlanmaktadır. Veriler ham halleriyle GeoMoS monitörde görselleştirilir. Bir prizma noktası ve yağmur sensörüne ilişkin bilgileri tablolar ve grafikler halinde birlikte gösterebilmektedir (GeoMoS Analyzer).

Kameralı insansiz hava arac1 incelemesi "The DJI PHANTOM"TM 4Pro (Capturing 20 megapixel stills)" cihazıyla yapılmış, heyelan sahasının farklı tarihlerde yerden kumandalı insansız hava aracı görüntüleri alınmıştır. İnsansız hava araçları lazer, GPS ve infra-red kameralar gibi farklı teknoloji ürünü cihazlarla donatılmıştır. $\mathrm{Bu}$ cihaz ile alınan hava fotoğrafları ortofotoya dönüştürülmüştür. Ortofotolardan NETCAD GIS yazılımıyla "heyelan kırıklılık haritası" elde edilmiştir (NETCAD GIS, K. Lisans: 7526). Bu harita üzerinde, heyelan öncesinde, geriye dönük belirli zaman aralıklarında kırıklılık gelişimini, her seferinde toplam kırık uzunluğunu ve yoğunluğunu görmek mümkün olmaktadır. Farklı dönemlerdeki kırıklar harita üzerinde farklı renklerde gösterilmektedir.

\section{Yağış ve Deformasyon Ölçümlerinin Zamana Bağlı Değişimi}

Deformasyon ölçümleri "GeoMos" yazılımıyla işlenmiştir. Şekil 4'te verilen grafik bu program kullanılarak elde edilmiştir. Ölçümler 10.02.2017 tarihinde başlatılmış ve günümüze değin sürdürülmüştür. Bu araştırmada 10.02.2017 ile heyelanın meydana geldiği tarih (19.12.2018) arasındaki 750 günlük süre içerisinde alınmış olan eş zamanlı yağış ve şev deformasyon ölçümleri verilmiştir (Şekil 5).
$\mathrm{Bu}$ zaman aralığında deformasyon ölçümleri grafikte, kümülatif (toplamalı) olarak 15 günlük aralıklarla sunulmuştur. Böylece, toplamda 50 veri grafikte görünmektedir. Zamana bağl1 deformasyon ölçümleri ve aynı tarihlerdeki yağış verileri kullanılan yazılımla otomatik olarak bir grafik üzerine aktarılmıştır. İlk kez deformasyonlar 19.05 .2017 'de başlamış, 06.07.2017'ye kadar devam etmiş ve alınan önlemlerle şev tekrar duraylı hale gelmiştir. Aynı tarihlerde yağış verilerinin de yükseldiği, hatta $05.05 .2017^{\prime}$ de saatte $2.75 \mathrm{~kg} / \mathrm{m}^{2 \prime}$ ye eriştiği görülmüştür (Birinci yağış rampası). 113 gün aradan sonra 24.10 .2017 'de Kasim ayı itibariyle yağışlar tekrar başlamış ve 26.01.2018'e dek sürmüştür (İkinci yağış rampas1). Oldukça yoğun yağışlar özellikle 2017'nin sonu ve 2018'in başında alınmıştır (Şeki1 5). Üçüncü yağış rampası (artış1) 10.02.2018 ile 12.04.2018 tarihleri arasında (Şubat-Mart-Nisan ayları) yer alır. Bu tarihten 17.11.2018 tarihine dek ara ara yağışlar olmuş ancak, günlük olarak yağış bir kez 23.0 kg/ $\mathrm{m}^{2}$ seviyesine erişmiştir (Şekil 5 ve 6). Genelde günlük $13.0 \mathrm{~kg} / \mathrm{m}^{2}$ nin altında seyretmiştir. İkinci, üçüncü yağış rampaları ve üçüncü yağış rampasından 17.11.2018 tarihine kadar ölçüm noktalarında kümülatif olarak deformasyonlar 5 $\mathrm{cm}$ ile $100 \mathrm{~cm}$ arasında değerler almıştır (Şekil 5). 09.02.2018 ile 02.11.2018 arasinda ortalama deformasyon (katlamalı bileşke yerdeğiştirmeler) $73 \mathrm{~cm}$ mertebesindedir (Şekil 5). 267 günlük bu dönemde ortalama yer değiştirme hızının 2.73 $\mathrm{mm}$ /gün olduğu belirlenmiştir. Deformasyon hızı, V>1.5 mm/gün Franklin (1977) tarafindan önerilen deformasyonlar için limit hız değeridir. Tüm yağış rampalarında limit değerlerin aşıldığ 1 ve üçüncü rampadan 17.11.2018'e kadar olan ve ara sıra yüksek yağışların olduğu dönemde de söz konusu limitin aşıldığ anlaşılmaktadır. 17.11.2018'de günlük $52.5 \mathrm{~kg}$ / $\mathrm{m}^{2}$ lik ölçülen en yüksek yağışla dördüncü yağış 
rampası başlamıştır (Şekil 6). Dördüncü rampa (yoğun yağış dönemi) 17.11.2018'de başlamış ve heyelanın gerçekleştiği ana kadar 32 gün sürmüştür. 17.11.2018 ve 18.12.2018 (Kasım - Aralık 2018) tarihlerinde açık ocak oldukça yükssek yağışlar almıştır (Şekil 6). Daha önceki dönemlerde de açık ocak yüksek yağışlar almış ancak, hiçbir zaman kümülatif bileşke toplam yer değiştirmeler (şev deformasyonları) 1.0 m'yi aşmamıştır. SMP-042, SMP-016 ve SMP-60 prizma noktaları deformasyon okuma farklarının en yüksek olduğu ölçüm yerleridir. Dördüncü yağış rampasının başlangıcından itibaren (17.11.2018) takip eden 13 günün sonunda (30.11.2018), SMP-042'de okunan deformasyon ölçümleri arasındaki fark 0.60 m'dir. Aynı zaman aralığında SMP-016'da bu fark 1.0 m'dir (Şekil 5). SMP-016'da 30.11.2018 ve 14.12.2018 (Topuk kazısı) tarihleri arasında da bu fark 1.0 $\mathrm{m}$ olarak ölçülmüştür. SMP-042'de hareketin hız1 $4.61 \mathrm{~cm} /$ gün, SMP-016'da ise her iki ölçüm döneminde de $7.69 \mathrm{~cm} /$ gün'dür. SMP-016'da şev hareketlerinin hızı SMP-042'den yaklaşık iki kat daha hızlı olarak gerçekleşmiştir. SMP-060'da 21.11.2018, 26.11.2018, 04.12.2018, 14.12.2018 ve 19.12.2018 tarihlerinde ölçülen toplam yer değiştirme miktarları sırasıyla $0.0,0.50 \mathrm{~m}, 1.0 \mathrm{~m}$, $2.50 \mathrm{~m}$, ve $10.5 \mathrm{~m}$ olarak gerçekleşmiştir (Şekil 6). Hareket hızları $8.33 \mathrm{~cm} /$ gün olarak başlamış ve 04.12.2018 tarihine dek devam etmiştir. Daha sonra hareketin hızı bir miktar artmış ve $10 \mathrm{~cm} /$ gün olmuştur. 14.12.2018'den başlayarak hız daha da yükselmiştir. Heyelan öncesindeki son 5 günde hareketin hızı giderekten artmış ve nihayet $160 \mathrm{~cm} /$ gün değerine erişmiştir (Şekil 6). $\mathrm{Bu}$ aşama, makaslama deformasyon birikiminin şev üst noktasına eriştiği ve şev topuğunda bu deformasyonların açık olarak gözlenebildiği (bu aşamada kayma yüzeyi artık gelişmiştir) aşamadır.

19.12.2018 sabah saat 03:00 sularinda heyelan oluştuğunda SMP-060 noktasinda ölçülen son toplam şev deformasyon miktarı (kümülatif bileşke yer değiştirme miktarı) 10.5 m'dir (Şekil 6). 18.12.2018 öğleden sonra ve 19.12.2018 sabahına dek geçen sürede ölçülen toplam yağış miktarı ise $29.4 \mathrm{~kg} / \mathrm{m}^{2 \prime}$ dir (Şekil 6).

SMP-042 ocak tabanından itibaren 7., SMP016 5. ve SMP-060 ise 6. basamağın üzerinde yer alır (Şekil 4). SMP-060 ve SMP-016 ölçüm noktaları ocak tabanına daha yakındır. SMP-060 iki ölçüm noktasının arasında, ancak SMP-016'ya daha yakın konumdadır. SMP-042 ve SMP-016 noktaları arasındaki topografik kot fark1 34 m'dir. Üç ölçüm noktası da kayma dairesi üzerinde yer alır. SMP-060 ve SMP-016 noktalarında göreceli makaslama gerilmeleri SMP-042'ye göre daha yüksek seviyelerde ölçülmüştür. $\mathrm{Bu}$ nedenle, bu noktalarda daha yüksek makaslama yer değiştirmeleri meydana gelmiştir. Bunun nedeni, SMP-060 ve SMP-016 noktaları kayan kütlenin ağırlık merkezine daha yakın konumdadır. Kütle ağırlık merkezinde, normal gerilmeler en yüksek değerdedir. Bu nedenle, makaslama gerilmeleri de en yüksek değerlere erişir. Böylece, bu ölçüm noktalarında daha yüksek makaslama deformasyonları oluşmuştur. 

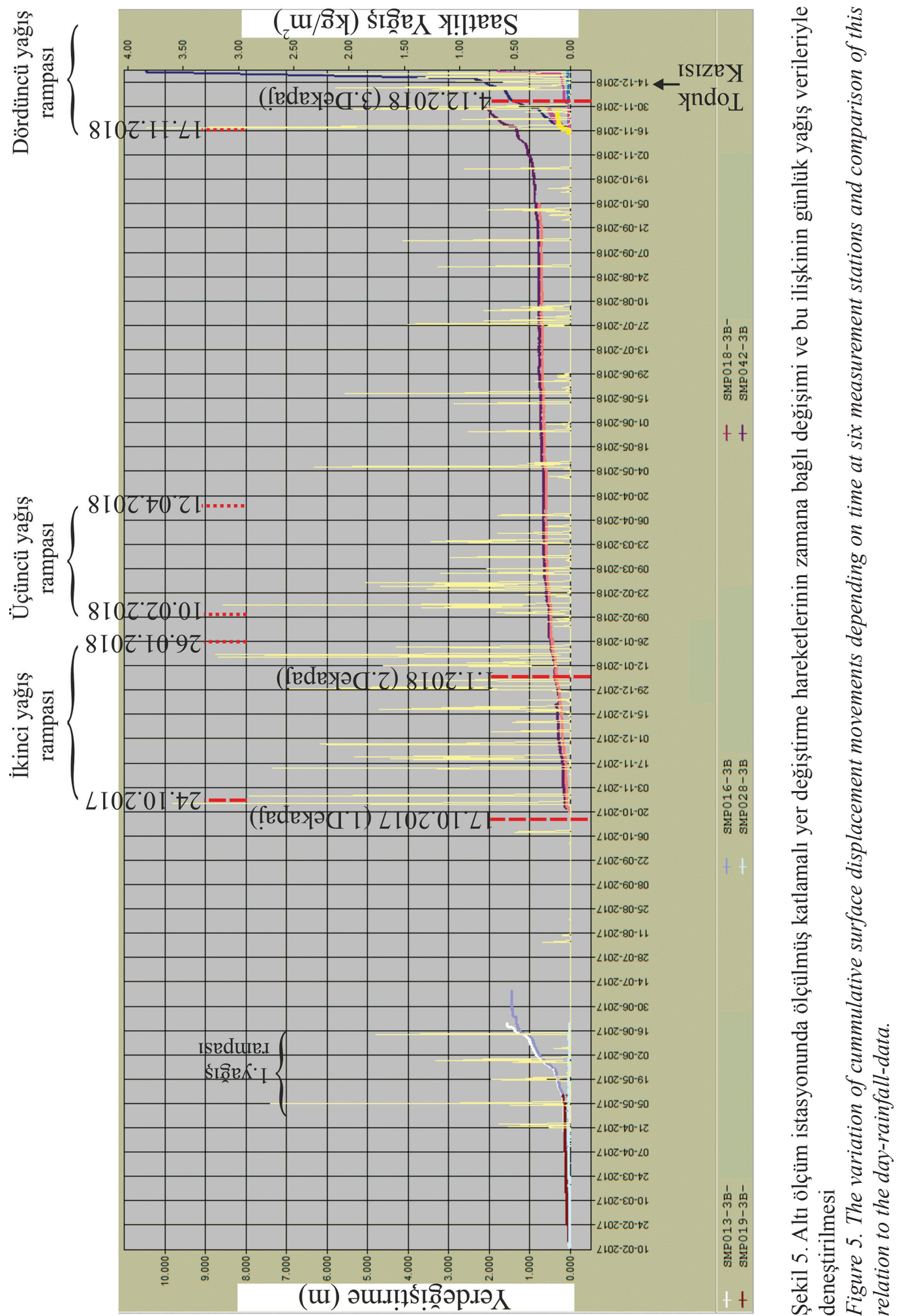

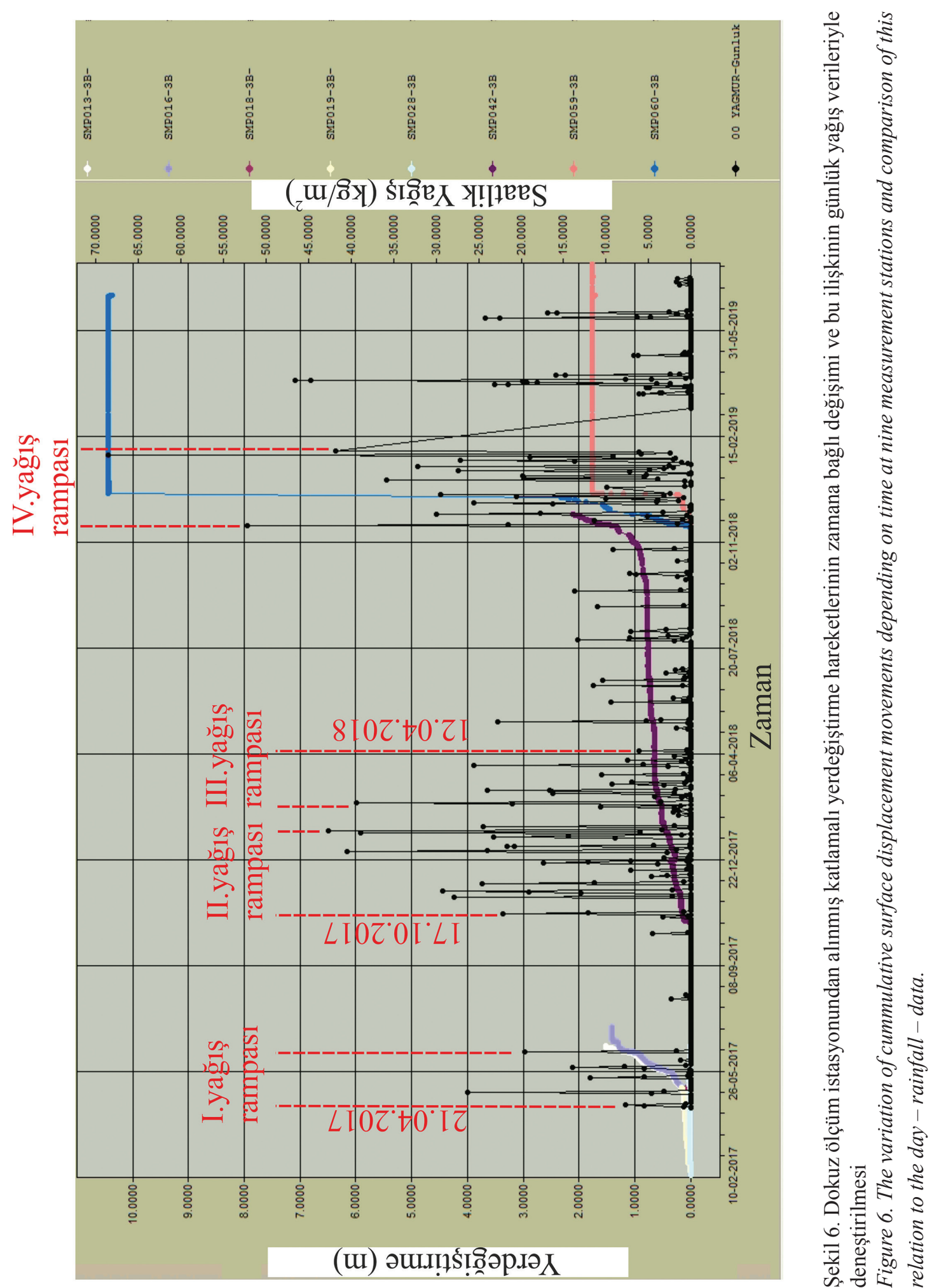


\section{Heyelana İlişkin Yüzey Kırıklılık Haritalaması}

Heyelan olmadan önce, 2018 y1lı içinde dört farklı tarihte $(02.10 .2018,02.11 .2018$, 12.11.2018 ve 04.12.2018 tarihlerinde) inceleme alanının insansız hava aracı görüntüleri alınmıştır. İnsansız hava aracıyla alınan hava fotoğrafları ortofotoya dönüştürülmüş ve ortofotolardan NetCad GIS yazılımıyla heyelan kırıklılık haritası elde edilmiştir (Şekil 7). Bu harita üzerinde çatlak gelişimini zamana ve olaylara bağlı olarak takip etmek mümkün olmaktadır. Her insansız hava aracı görüntüsüne ait yüzey kırıkları Şekil 7'deki haritada farklı renklerde takip edilmektedir. 12.11.2018'de büyük heyelan oluşmadan önce, daha küçük boyutlu, öncü bir heyelan meydana gelmiştir (Gerilme çatlakları mavi renklerde görüntülenmiş alan). Küçük heyelan büyük heyelanın doğu kanadında yer almaktadır (Şekil 7). Buna ek olarak, KB'ya kayma eğilimi nedeniyle batı kanadında da KD'ya doğru çekme gerilmelerinin meydana gelmesine neden olmuştur. 30.11.2018'de yer değiştirmeler SMP016 ve SMP-042'de 1.0 m olarak ölçülmüştür. Öncü, küçük heyelan 12.11.2018 tarihinde meydana geldiğinde, SMP-042'de kümülatif yer değiştirmeler 1.50 m'ye erişmiştir. Bu tarihten 19 gün sonra $30.11 .2018^{\prime}$ de ise 2.0 m'ye ulaşmıştır. 19 günde 0.50 m'lik kümülatif bileşke yer değiştirmeler gerçekleşmiştir ( $V=26.3 \mathrm{~mm} /$ gün$)$. Yukarıda ölçülen yer değiştirmeler, ana heyelanın batı kanadında KD'ya doğru (ana kayma yönüne doğru) çekmelerin geliştiğini işaret etmektedir. $\mathrm{Bu}$ yönün doğruluğunu, kayma sonrasında heyelanın batı kanadında kayma hareketlerinin neden olduğu yerli kayaç yüzeyinde meydana gelen kayma çiziklerinin yönelimi göstermiştir.

\section{Heyelanın Öncesinde ve Sonrasında Aynı Hattan Alınmış Topoğrafik Kesitlerin Çakıştırılması}

Farklı zamanlarda gerçekleştirilen şev iyileştirme, inceltme kazıları ve su drenajı gibi önlemlerlesaha zaman zamanrehabilite edilmiştir (Şekil 8). Ekim 2011'de (17.10.2011, birinci dekapaj çalışması) şev üst yüzeyinde gözlenen gerilme çatlaklarıyla heyelan oluşum süreci başlamış ve farklı dönemlerde iki kez önemli artışlar göstermiştir. 2011'de genel şev açısının $30^{\circ}$ olması, gerilme çatlaklarının oluşumunu açıklamaktadır. Burada $30^{\circ}$ 'lik genel şev açısı, önerilenden $6^{\circ}$ daha yüksektir. 17.10.2011Birinci dekapaj çalışması, 01.01.2018- İkinci dekapaj çalışması, 04.12.2018- Üçüncü dekapaj çalışması ve 19.12.2018 tarihlerinde $\mathrm{A}-\mathrm{A}^{\prime}$ hattı boyunca alınmış topoğrafik kesitlerin çakıştırılması ve olası kayma dairesinin konumu Şekil 8'de verilmiştir. Buna ek olarak, aynı kesitte cevher kütlesinin ve nihai genel şev açısının $\left(\alpha_{\text {overall }}=25^{\circ}\right)$ konumları da gösterilmiştir. Farklı tarihlerde, aynı hat üzerinde (K50B) alınmış topoğrafik kesitlerin çakıştırılması, yapılan dekapaj kazılarının miktarını (dekapaj miktarını) şevin yedi y1llık gelişimini (2011-2018 yılları arası), heyelan sonrasında oluşan genel şevin konumunu $\left(\alpha_{\text {overall }}=\right.$ $21^{\circ}$ ), şev üst kesimlerindeki kayarak hareket eden kütlenin toplam yer değiştirme miktarını ve daha alt şev kademelerinde doldurduğu yerleri görmeyi mümkün k1lmaktadır (Şekil 8). Buna ek olarak, farklı tarihlerde alınmış topoğrafik kesitlerin hem şev üst noktasında $\left(\mathrm{h}_{1}=463.5 \mathrm{~m}\right)$ hem de şev tabanındaki $\left(\mathrm{h}_{2}=410 \mathrm{~m}\right)$ kesişme noktaları gerçek şev yüksekliğini belirtmektedir (Geri analizlerde bu yükseklik dikkate alınmalıdır). 04.12.2018 (Üçüncü dekapaj çalışması) ve 19.12.2018 tarihlerinde alınan topoğrafik kesitler sirasıyla heyelan öncesindeki en son ve heyelan oluşumu sonrasındaki ilk kesitlerdir. $\mathrm{Bu}$ kesitlerin şev üst noktasında ve şev topuğundaki 
kesim noktaları arasındaki yükseklik farkı $\left(\mathrm{h}_{1}-\mathrm{h}_{2}\right.$ $=53.5 \mathrm{~m}$ ) $53.5 \mathrm{~m}$ ' dir ve bu değer heyelan etmiş kütlenin gerçek yüksekliğidir. Çünkü 04.12.2018 öncesindeki topoğrafyaya ait malzemeler gerek inceltme kazıları gerekse de cevher üretimine yönelik dekapajla (overburden removal) alınmıştır. Ekim 2011'de meydana gelen gerilme çatlaklarının yer aldığ 1 şev üst yüzeyi de dikkate alındığında bu yükseklik $(490-410=80 \mathrm{~m}) 80$ m'ye erişmektedir. Stabilite analizleri sonucu önerilen nihai şev açısı (final overall slope angle) $24^{\circ}$ dir. Ancak 2011 yılında (17.10.2011-birinci dekapaj çalışması) üretime $30^{\circ}$ genel şev açısında başlanmıştır (Şekil 8). Bu durum, şev gerisinde ilk kez gerilme çatlaklarının oluşmasına neden olmuştur. 01.01.2018'de gerçekleştirilen dekapajla (ikinci dekapaj çalışması) genel şev eğimi arttırılmış ve şev gerisinde ikinci kez gerilme çatlakları oluşmuştur (Şekil 9). 04.12.2018'de alınan topoğrafik kesitten (üçüncü dekapaj çalışması sonunda) genel şev açısının $25^{\circ}$ ye eriştiği anlaşılmıştır (Şekil 9). Cevher üretimine yönelik şev topuğunda kazı 14.12.2018'de yapılmış ve genel şev açısı daha da arttırılmıştır. Böylece, 415 m kotuyla o günkü ocak tabanı $(384 \mathrm{~m})$ arasındaki şev kesiminde $(\mathrm{H}=31 \mathrm{~m})$ genel şev açısı $33^{\circ}$ ye çıkmıştır (Şekil 9). Topukta şev açısının artması, genel şev açısını da arttırarak önerilen sınır değerin $(\alpha=$ $24^{\circ}$ ) üzerine çıkmasına neden olmuştur (Şekil 9). Bu durum, 19.12.2018'de meydana gelen ana heyelanı tetiklemiştir ve yoğun yağışlarla birlikte heyelanın oluşum nedenlerinden biri olarak ortaya çıkmıştır.

\section{Heyelan Öncesinde Gözlenen Deformasyonların Yorumlanması ve Yenilme Mekanizmasının Yorumu}

Açık ocak işletmesinde 19.12.2018 tarihinde iki düzlemli kayma yenilmesi şeklinde bir mekanizmaya sahip büyük ölçekli bir heyelan meydana gelmiştir (Şekil 8 ve 9). Heyelan hareketi 410 ve $490 \mathrm{~m}$ kotları arasında yer alan sik çatlaklı, ayrışmış gnaysları etkilemiştir. Heyelan öncesi başlangıç aşamasında şev tepesinde ve basamaklarda meydana gelen gerilme çatlakları veyüzeysel dökülmeler (heyelan başlangiç tepkisi safhas1), daha sonra heyelanın şev topuğuna yakın kesimlerindeki kademelerde meydana gelen kabarmalar (heave) ve nihayet kaymanın meydana geldiği an aşama aşama fotoğraflanarak belgelenmiştir (Şekil 10, 11 ve 12). Kaya şevlerinde zamana bağlı deformasyonlar üç belirgin aşamadan geçer. Birinci aşama olan başlangıç tepkisi safhası, kazı nedeniyle kütlede meydana gelen gerilme değişimlerini kapsar ve kayaç kütlesinin dilatasyonu veya gevşemesi ile sonuçlanır (Martin, 1993). Heyelan hareketiyle ilgili en önemli belirteç; kayma öncesinde yüzeyde gözlenen gerilme çatlaklarının yanısıra şev topuğuna yakın kotlardaki kabarmalar ve küçük ölçekli yer değiştirmelerdir. 


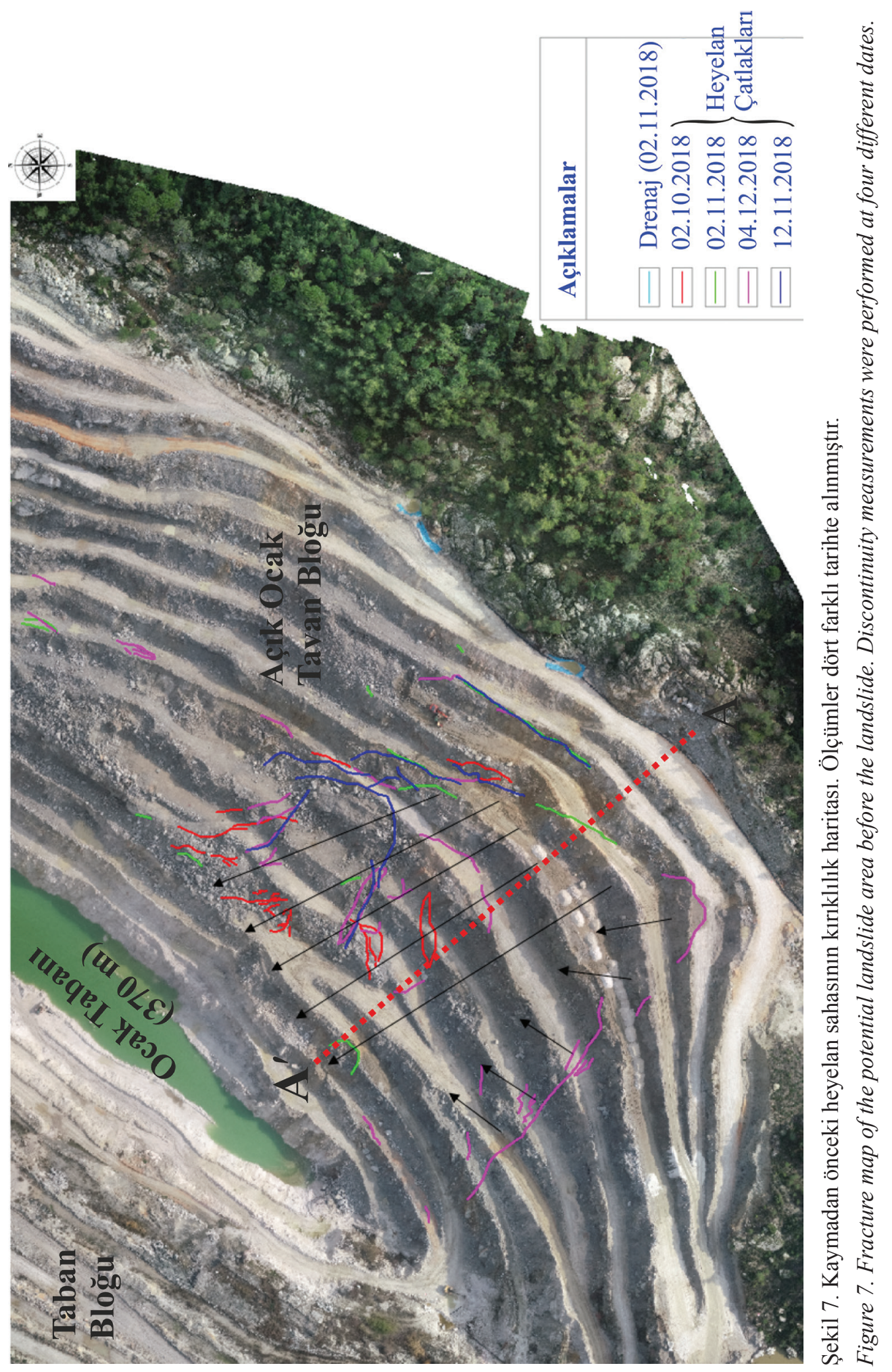




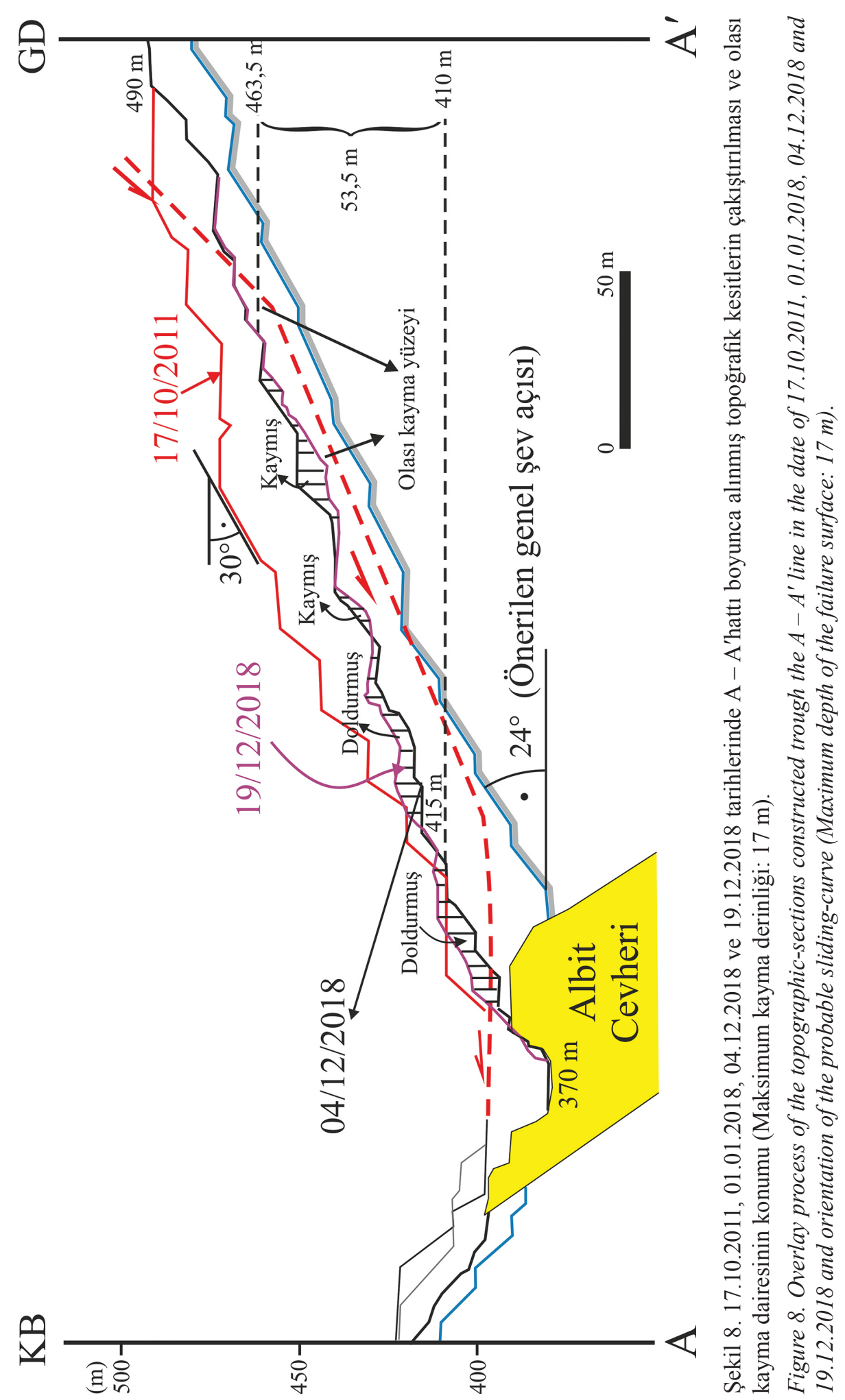




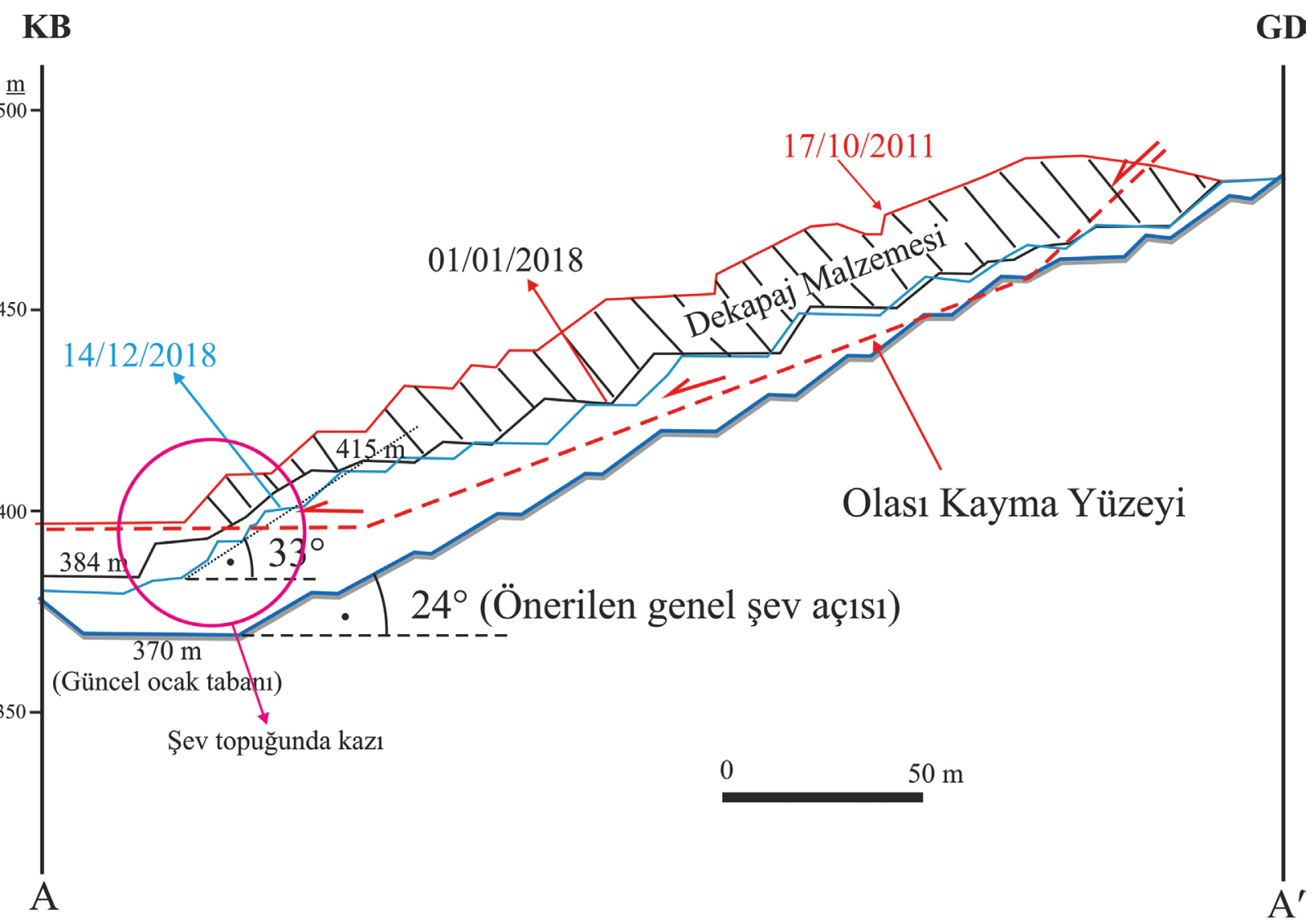

Şekil 9. 01.01.2018'de yapılan inceltme kazısı ve 04.12.2018'de şev topuğunda üretim amaçlı yapılan dekapaj çalışmaları sonucu şev eğiminin artması.

Figure 9. Increasing the dip angle of the overall slope as a result of the works of overburden removal at the date of 01.01.2018 and 04.12.2018 for the aim of the ore-production at the slope-toe.

Heyelan hareketi öncesinde, sadece elastik yer değiştirmeler kayaç kütlesinin hareketlenmesine veya kalkmasina neden olur (Call ve Savely, 1991; Sjöberg, 1999; Simon vd., 2012). Elastik yer değiştirmeler, kalkma şeklinde yükselmeler, şev topuğuna yakın kotlarda makaslama deformasyon oluşumları/birikimlerini meydana getirmiştir. $\mathrm{Bu}$ deformasyonlar açik ocak şevlerinde (topuğa yakın şev kademelerinde) yüzeysel dökülmeler ve kabarmalar şeklinde ortaya çıkmıştır (Başlangıç tepki safhası), (Şekil 10). Makaslama deformasyon birikimleri (shear strain accumulation) açık ocakta $410 \mathrm{~m}$ kademesinde başlayarak hafifçe artan yer değiştirmelerle şev yukarısına doğru ilerlemiştir (Şekil 10). $\mathrm{Bu}$ aşamada günde $1 \mathrm{~cm}-5 \mathrm{~cm}$ seviyesinde yer değiştirmeler ve şev topuğunda kabarmalar şeklinde deformasyonlar gözlenmiştir (Şekil 10). Makaslama deformasyon birikimlerinin şev tepesine erişmesi, kayma yüzeyinin oluşması (Şekil 11 ve 12) ve büyük yer değiştirmelerin gelişmesi şev topuğundaki örselenmeye bakılarak anlaşılmıştır. Son aşamada, yenilen kütle şevden kayarak uzaklaşmıştır (19. 12. 2018). 
Genelde foliasyon düzlemleri genel şev yüzeyini kesmez $\left(\alpha_{\text {overall slope }}<\alpha_{\text {foliasyon }}\right)$. Bu nedenle, şevde yüzeylemezler. Fakat, şev içerisinde, hafifçe şev tabanına eğimli (açık ocağa eğimli) bir zayıflık düzlemi oluştururlar. $30^{\circ}$ ye yakın eğim değerlerinde olanlar şev yüzeyine $\left(\alpha_{\text {overall slope }}=25^{\circ}\right)$ yaklaşık paralel bir uzanım gösterirler (an ubiquitous discontinuity set). Bu konumdaki foliasyonlar, genelde açık ocakta regresif yenilmelerin en yaygın olan özelliğidir (Call vd., 2000). Açık ocağa eğimli foliasyonlar genel şev yüzeyine paralel konumda birer gerilme hattı oluşturmuş ve şev hareketlerini bu hizada arttırmıştır. Buna ek olarak, şev topuğuna doğru foliasyon yüzeylerinde giderekten artan gerilmeler, topukta çatlaklı yapının yayılmasına da neden olmuştur (Şekil 13). Bu durum, yenilmenin hemen öncesinde şev topuğunda 0.5 $1.0 \mathrm{~m}$ kalınlığa ulaşan makaslama deformasyon zonunu oluşturmuştur (makaslama nedeniyle aşırı örselenme zonu). Bu deformasyonlar artık, makaslama zonu boyunca kütlenin şev dişına doğru kayacağına dair en önemli verilerdir.

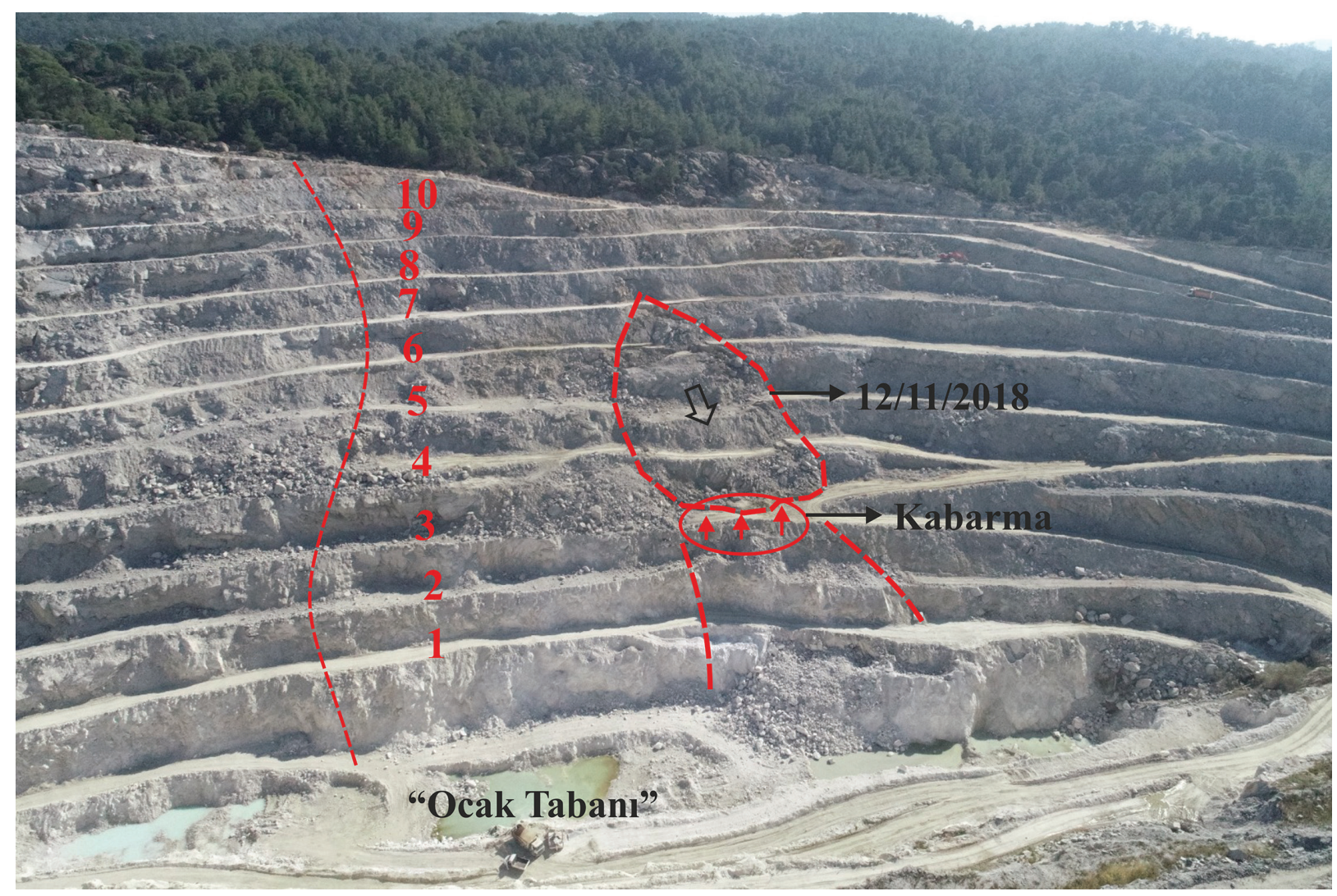

Şekil 10. Yenilme öncesindeki ilk şev deformasyonları ve 12.11.2018'de meydana gelen öncü-küçük heyelan (1, 2, $3, \ldots . ., 10$ : şev kademeleri).

Figure 10. First slope-movements (displacements) and small-scale landslide occurrence before the large-scale landslide at the date of 12.11.2018 (1, 2, 3,...,10: slope benches). 


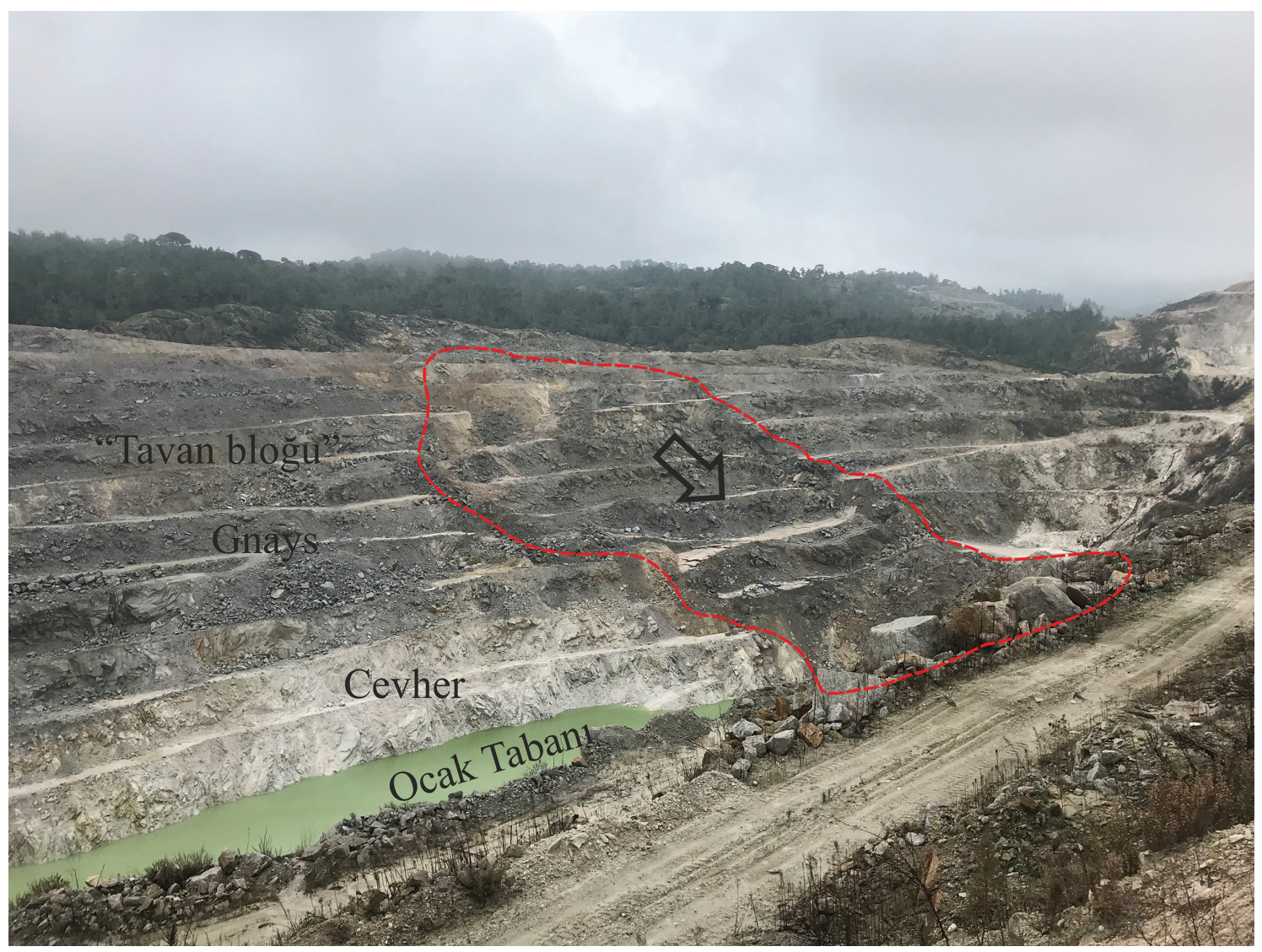

Şekil 11. Kayma yüzeyinin şev topuğunda gnaysı kesmesi (cevheri kıramamıştır).

Figure 11. Intersection of the sliding-curve and the gneiss (could not cut the ore-body).

Diğer taraftan, foliasyon düzlemleri genel şevi kesmemesine karşın, şev kademelerini kesmektedir $\left(\alpha_{\text {overall slope angle }}<\alpha_{\text {bench face angle }}\right)$, (Şekil 13). Yenilme, genel şevin topuğuna yakın bir kottaki kayaç kütlesi boyunca makaslamayı ve süreksizlikler (foliasyonlar) üzerinde kaymayı kapsar (Şekil 13). Açık ocak işletmesi heyelanı oldukça sı̆̆ yenilme yüzeyine sahiptir (Şekil 11 ve 12). Yenilme yüzeyi başlangiçta hemen hemen şeve paralel uzanır, daha sonra, şeve yönelerek şevi kesmektedir. $\mathrm{Bu}$ nedenle, başlangıçtan itibaren düşünüldüğünde hareket göreceli yavaştır. Cevher üretimi devam ettikçe şev yüksekliği artmaktadır. Buna bağlı olarak yeni şev geometrileri oluşmakta ve böylece gerilmeler de şev topuğunda artmaktadır. Gerilmelere bağlı olarak gelişen makaslama deformasyonları foliasyon düzlemlerinin şev topuğuna yakın kesimlerde eğimleri nedeniyle maksimum olmaktadır (principal stress aligns). Heyelan sahasında gnayslar oldukça ayrışmış (HW) olup, zayıf kayaç özelliğindedir ve oluşturdukları genel şev açısı $25^{\circ}$ olmasına karşın heyelan etmişlerdir. Kayma yönünde alınan kesitlerden elde edilen heyelan geometrisi, aşağı yukarı belli bir doğrultuyu takip eder (Şekil 12, düzlemsel yenilme), fakat enine alınmış kesitlerinde yenilme yüzeyi, hafif eğrisel bir yüzeye sahiptir. 


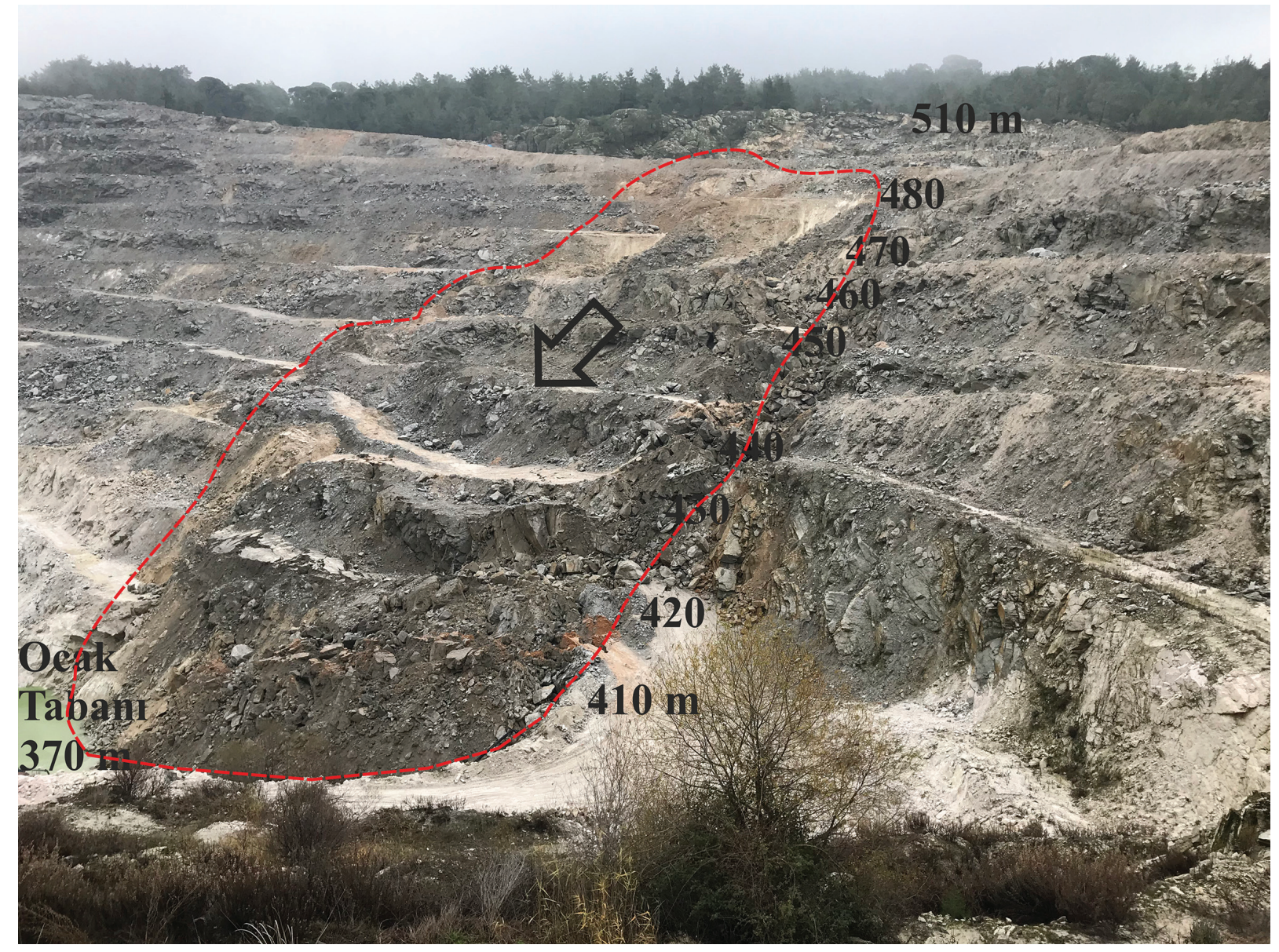

Şekil 12. Heyelan sonrası oluşan topoğrafya (19.12.2018, sabah: 7:30).

Figure 12. Topography after the landslide (19.12.2018, 7:30 am).

Böylece, gerilme çatlağından itibaren yaklaşık düşey ve daha sonra şev yüzeyine yaklaşı paralel konumlu foliasyon düzlemini takip eden bir yenilme yüzeyi oluşmuştur. Şev topuğuna yakın yerde bu yüzey şev dışına dönerek şevi kesmektedir (Şekil 13). Sonuçta, foliasyon yüzeyleri boyunca kaymay1, şev topuğuna yakın kesimlerde sık çatlaklı kayaç kütlesinde makaslamaları içeren gerilme çatlaklı ve foliasyon kontrollü bir yenilme yüzeyi oluşmuştur (Şekil 13). Gerek süreksizlikten itibaren gelişmiş gerilme çatlağ 1 (82-90/40-70) gerekse de foliasyonlar (210-270/26-40) dikkate alındığında, yenilmenin süreksizlik kontrollü kombine bir hareket olduğu ortaya çıkmaktadır. $\mathrm{Bu}$ nedenle, çalışmada, sık çatlaklı kayaçlarda (belirgin yapısal öğeler bulunmuyorsa) gelişen "eğrisel kayma yüzeyine sahip heyelan" terimi (Rotational shear failure and/or circular failure) kullanılmamıştır. $\mathrm{Bu}$ terim yerine, kullanımda rotasyonel ve düzlemsel makaslama yenilmelerini içeren "gerilme çatlaklı, iki düzlemli kayma yenilmesi" terimi (sliding failure with two planars including rotational shear and plane shear failures) tercih edilmiştir. 


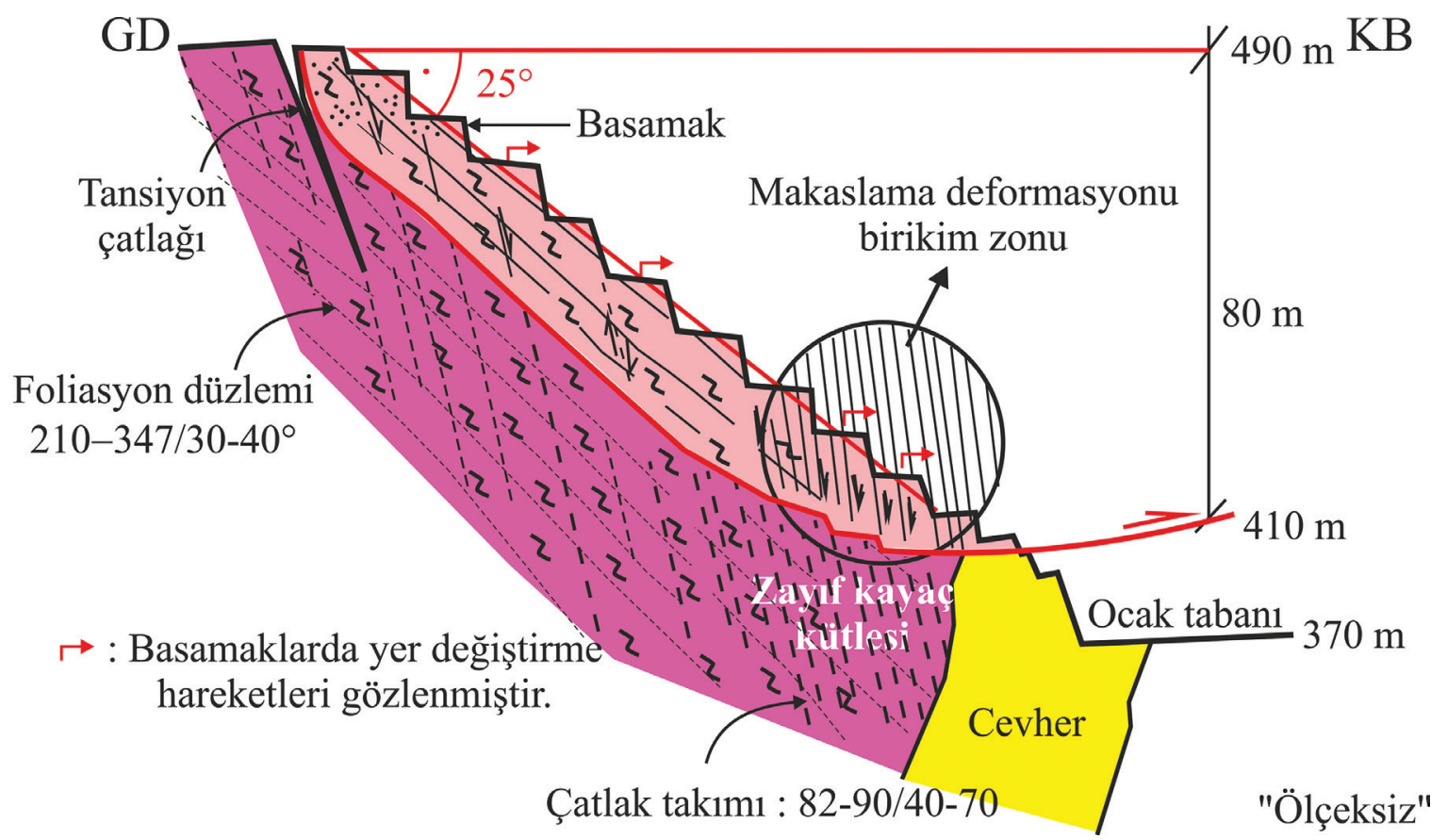

Şekil 13. Şev yüzeyine yaklaşık paralel konumdaki foliasyon düzlemlerinin şev topuğuna yakın kesimlerinde çatlaklı yapı oluşturması ve sı̆̆ derinlikte foliasyon kontrollü yenilme yüzeyi (Dairesel ve düzlemsel makaslama yenilmeleri).

Figure 13. Forming the jointed structure at the elevation near the slope-toe due to the foliation planes which are oriented nearly parallel to the slope face and failure surface controlled by the foliations at shallow depth (Rotational and plane shear failures).

\section{Potansiyel Heyelan Alanı ve Gözlenen Heyelan Alanının Karşılaştırılması}

2014 yılında açık ocakta heyelan potansiyeline sahip topoğrafyanın yüzey alanı $62800 \mathrm{~m}^{2}, 19.12 .2018$ 'de gerçekleşen heyelanın yüzey alanı ise $21040 \mathrm{~m}^{2}$ olarak MapInfo Professional 8.0 (2000) yazılımı kullanılarak ölçülmüştür. $\mathrm{Bu}$ alanların konumları ve koordinatları Şekil 14'te sunulmuştur. 2014 ile 2018 yılları arasında şev kazısıyla 41760 $\mathrm{m}^{2}$ lik alan cevher üretimine yönelik olarak alınmıştır. Heyelanın yüzey alanı 2014'te öngörülen potansiyel heyelan sahasının üçte biri kadardır. Bunun nedeni, 01.01.2018 ve 04.12.2018 tarihlerinde gerçekleştirilen ikinci ve üçüncü dekapaj çalışmaları ve şev yüksekliğini azaltmaya yönelik inceltme kazılarıdır.
Potansiyel heyelan alanı, K-G yönünde şev kademelerine paralel uzanmış bir görüntü vermiştir (Şekil 14). Alanın tamamı eski dere yataklarının denetimi altındadır. 19.12.2018'deki heyelanın nedenlerinden biri olan ana dere, heyelanın kayma yönünde (K50B) bir uzanıma sahiptir ve heyelanın GB kanadını oluşturmuştur. Ana derenin kollarından biri şev kademelerine paralel uzanırken diğeri, kademeleri dar açı yapacak şekilde kesmektedir. $\mathrm{Bu}$ veriler, 2014'deki açık ocakta yan yana iki adet potansiyel sahanın varlığına işaret etmektedir. Biri ana derenin akış yönünde diğeri ise, ana dereyi besleyen iki kolun denetimindedir. 


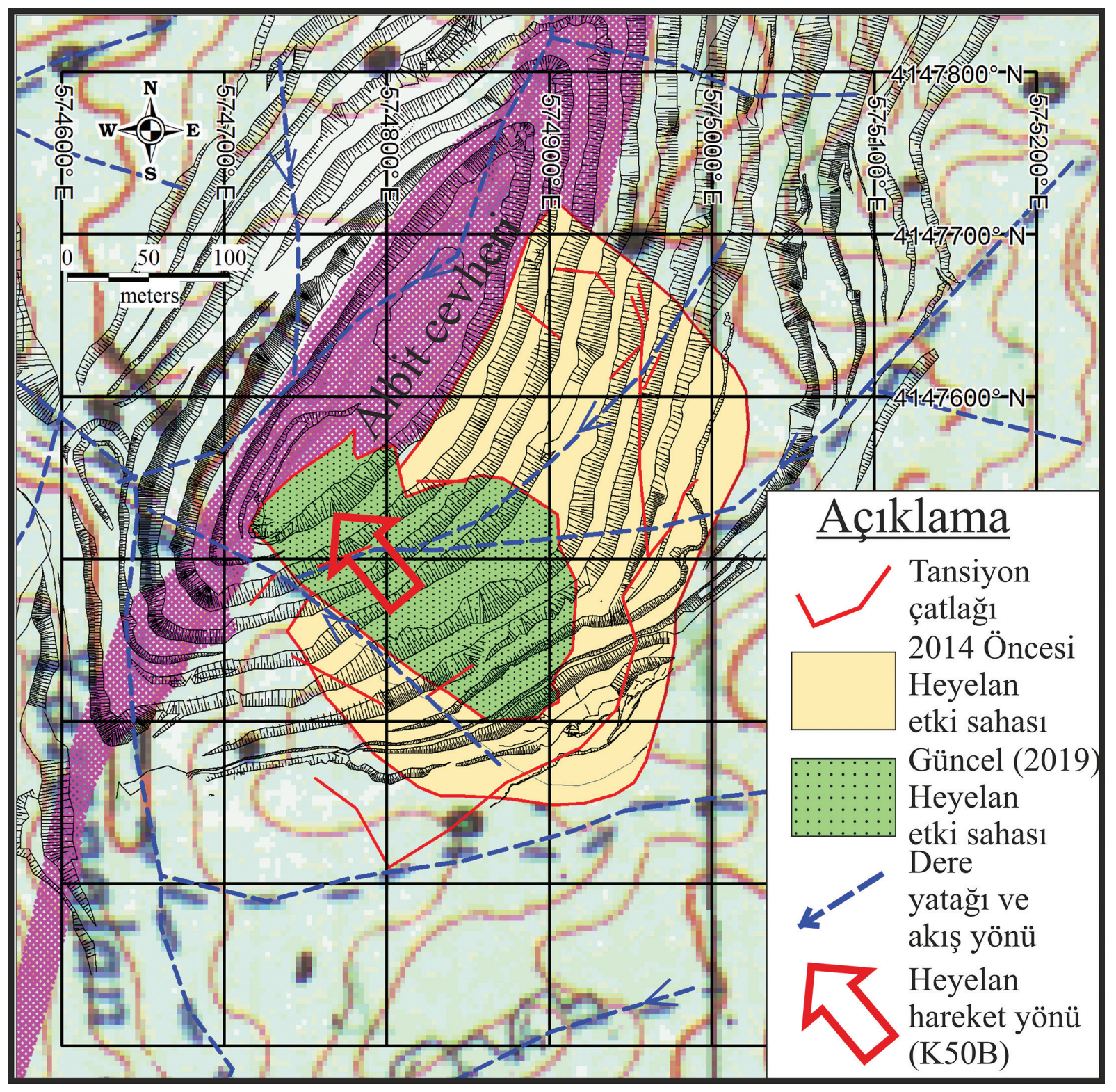

Şekil 14. Potansiyel ve gerçek heyelan sahalarının yüzey alanlarının karşılaştırılması.

Figure 14. Comparison of the potential and the real landslide surface areas.

\section{TARTIŞMA}

Açık ocak işletmesinin güneydoğusunda üçüncü şev dekapajıyla birlikte genel şev açısı $25^{\circ}$ ye erişmiş ve zamana bağlı kümülatif yer değiştirmeler ve şev hareketlerinin hızı, o tarihten itibaren ivmelenerek artmıştır (Şekil 15). Şevdeki önemli deformasyonlar 14.12.2018 tarihindeki kontrolsüz topuk kazısıyla başlamış ve o tarihten itibaren şev hareketleri progresif yenilme durumunu yansıtmıştır (Şekil 15). 
Herhangi bir açık ocakta yer alan bir şevdeki koşullar başlangıçta regresif durumu yansıtırken daha sonra progresif aşamaya geçebilir. Doğal olarak, progresif duruma geçmek için sabit hızla sürekli durum devam ederken kayda değer bir yer değiştirme hareketinin gerçekleşmesi gerekmektedir. Şevde kayda değer yer değiştirme hareketi 14.12.2018'de cevher üretimine yönelik topukta gerçekleştirilen kontrolsüz kazı ile başlamıștır. Böylece, șev eğimi artmıștır. Buna ek olarak, 17.11.2018 itibarıyla yılın en yağışl1 dönemi başlamıştır (Dördüncü yağış rampas1). Üçüncü dekapaj çalışmasıyla (04.12.2018) 14.12.2018 (topuk kazısının yapıldığı gün) tarihleri arasında toplam bileşke hareket miktarı $100 \mathrm{~cm}$ artmıştır ve hareketin hızı $10 \mathrm{~cm} /$ gün olarak belirlenmiştir. 14.12.2018 tarihinden sonraki beş günlük zaman aralığında SMP-060 noktasında hareketin hızı $160 \mathrm{~cm} /$ gün olarak elde edilmiştir (Şekil 15).

Özellikle cevher üretimine yönelik şev topuğunda yapılan kazıların genel şev açısını aşmayacak şekilde yapılmasını zorunlu kılmaktadır. $\mathrm{Bu}$ nedenle, şev kazılarıyla ilgili uygulamalarda açık ocak mühendislerinin daha duyarlı davranmaları (hassas nivelman ölçümleri yapılarak kazıya başlanmalıdır) gerekmektedir.

Yoğun yağışları takip eden dönemlerde şevlerin stabilitesi bozulmakta ancak, drenaj gibi şev iyileştirme çalışmalarıyla stabilite tekrar sağlanmaktadır. Bir diğer anlatımla, stabilite üzerine olumsuz etkiye sahip etmen ortadan kaldırıldığında, şevin stabilitesi tekrar eski durumuna kavuşmakta ve açık ocakta cevher üretimine devam edilebilmektedir.
$\mathrm{Bu}$ tür regresif hareketlerde zamana bağl1 yer değiştirme grafikleri basamaklı bir yap1 sunmaktadır (birinci yağış rampası). Zamana bağlı hız değişim grafiği ise, önce artan sonra azalan bir seyir takip etmektedir. Diğer taraftan, progresif hareketlerde zamana bağl1 hareketin hızı ve yer değiştirme miktarı devamlı artmakta ve heyelan oluşumuna kadar bu artış devam etmektedir. 19.12.2018 tarihinde gerçekleşen heyelan belirlenen özellikleriyle progresif bir hareketi tanımlamaktadır.

Zamana bağlı olarak alınan deformasyon ölçümleri, farklı zamanlarda, heyelan öncesinde ve sonrasında alınmış topoğrafik kesitlerin çakıştırılması, insansız hava aracı görüntülerinden elde edilen heyelan gelişimine ait belirteçler ve yerinde yapılan günlük gözlemler sonucunda, heyelan öncesinde oluşan şev deformasyonları Şekil 16'daki gibi modellenmiştir.

Foliasyon düzlemleriyle çatlakların yaklaşık birbirine dik olması şevdeki blok oluşumunu sağlamaktadır (Şekil 16). Foliasyonların genel şev yüzeyine yaklaşık paralel olması, genel şev kaymasının meydana gelmesini kinematik olarak mümkün k1lmaz $\left(\alpha_{\text {foliasyon }} \geq \alpha_{\text {overall }}\right)$. Diğer taraftan, madencilik faaliyetleri nedeniyle (topukta yapılan hafriyat sebebiyle) oluşan gerilme artışları, şev tepesinden (gerilme çatlakları oluşumu) şev topuğuna (kabarma meydana gelmesiyle) transfer olur. Bu transferin sağlanmasinda foliasyonlar etkin rol oynar. Sonuçta; şev topuğunda yer alan kayaç kütlesi daha kırıklı/sık çatlaklı hale gelir ve topukta makaslama yer değiştirmelerinin meydana gelme eğilimini arttırır. 


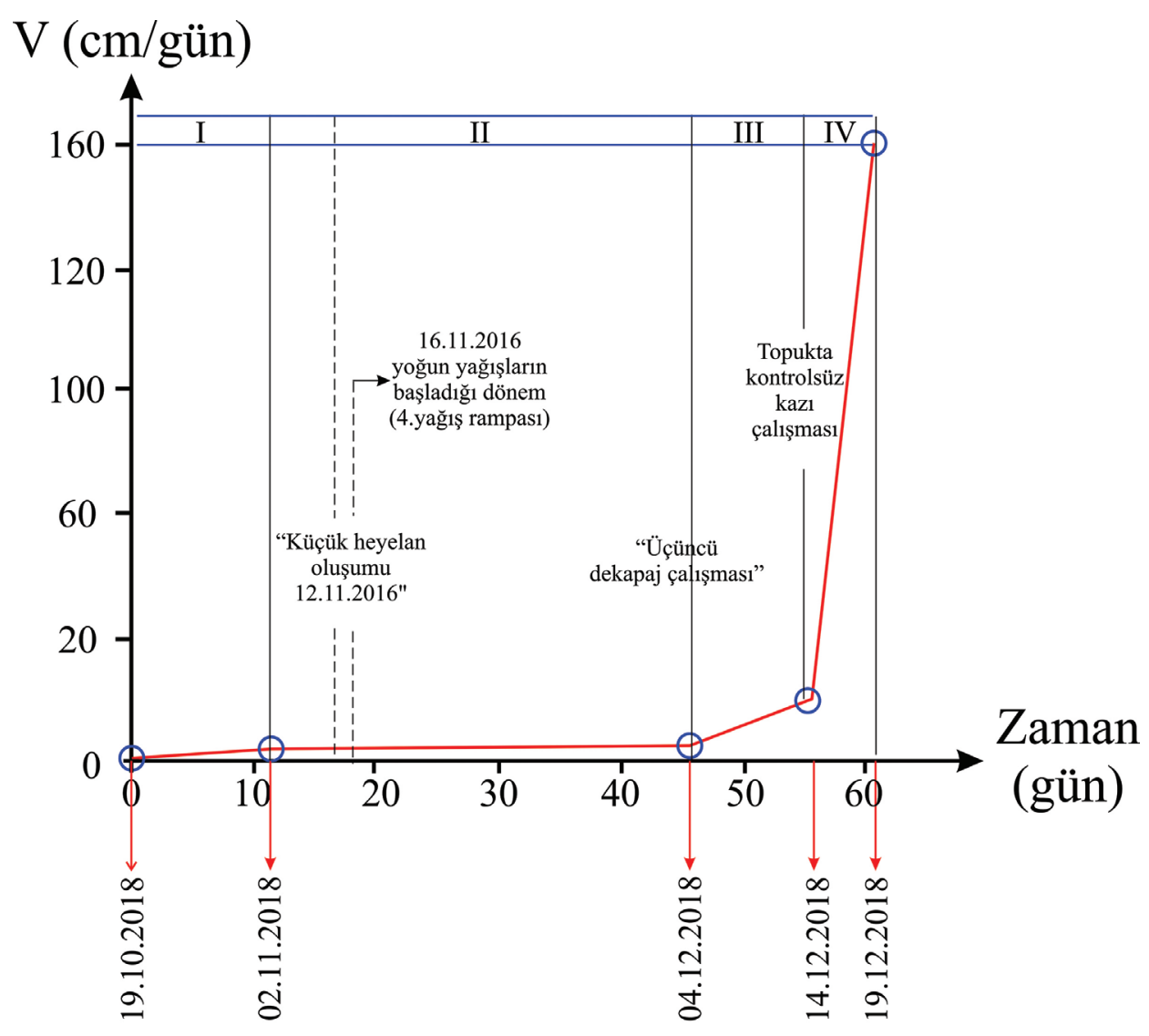

\section{I, II ve III : Regresif aşamanın zonları}

IV : Progresif evreye geçiş zonu

Şekil 15. Şev hareket hızı ve zaman arasındaki ilişki (14.12.2018'den önce şev deformasyonları sabit hızda ilerlemiştir ve daha sonra kayan kütle ivmelenmiş veya aktive olmuştur).

Figure 15. Relationship between the velocity of slope movement and time (Slope deformations had progressed at a constant speed before the date of 14.12.2018 and later activated or accelerated the movement of the sliding mass).

\section{SONUÇLAR}

Heyelan, açık ocağın GD şevinde 490 m ile $410 \mathrm{~m}$ kotları arasında meydana gelmiştir $\left(h_{\text {overall }}\right.$ $=80 \mathrm{~m}, \alpha_{\text {overall slope }}=25^{\circ}$ ). Açık ocak işletmesinin GD'da meydana gelen heyelanın ana nedeni, Yarenalan Deresi'nin kolları boyunca dere sularının ocağı beslemesidir. Şev planlaması sırasında şev basamakları teşkil edilmiş ve dere yataklarının yönü değiştirilmiştir. Ancak gömülü eski dere yataklarının faaliyetlerini derinden sürdürdüğü belirlenmiştir. Çalışan gömülü dere yatakları boyunca gelen sızıntı suları gnaysları etkilemiştir. Yumuşamaya bağlı olarak makaslama dayanım parametreleri $(c, \varphi)$ azalmıştır. Buna ek olarak, mevcut süreksizlikler boyunca kohezyonun kaybolmasina neden olmuştur. Bunun en önemli verisi, yer değiştirme hareketlerinin başlamış olmasıdır. Bu durum, açık ocak şevlerinde kayma koşullarını hazırlayan parametrelerden birisidir. 


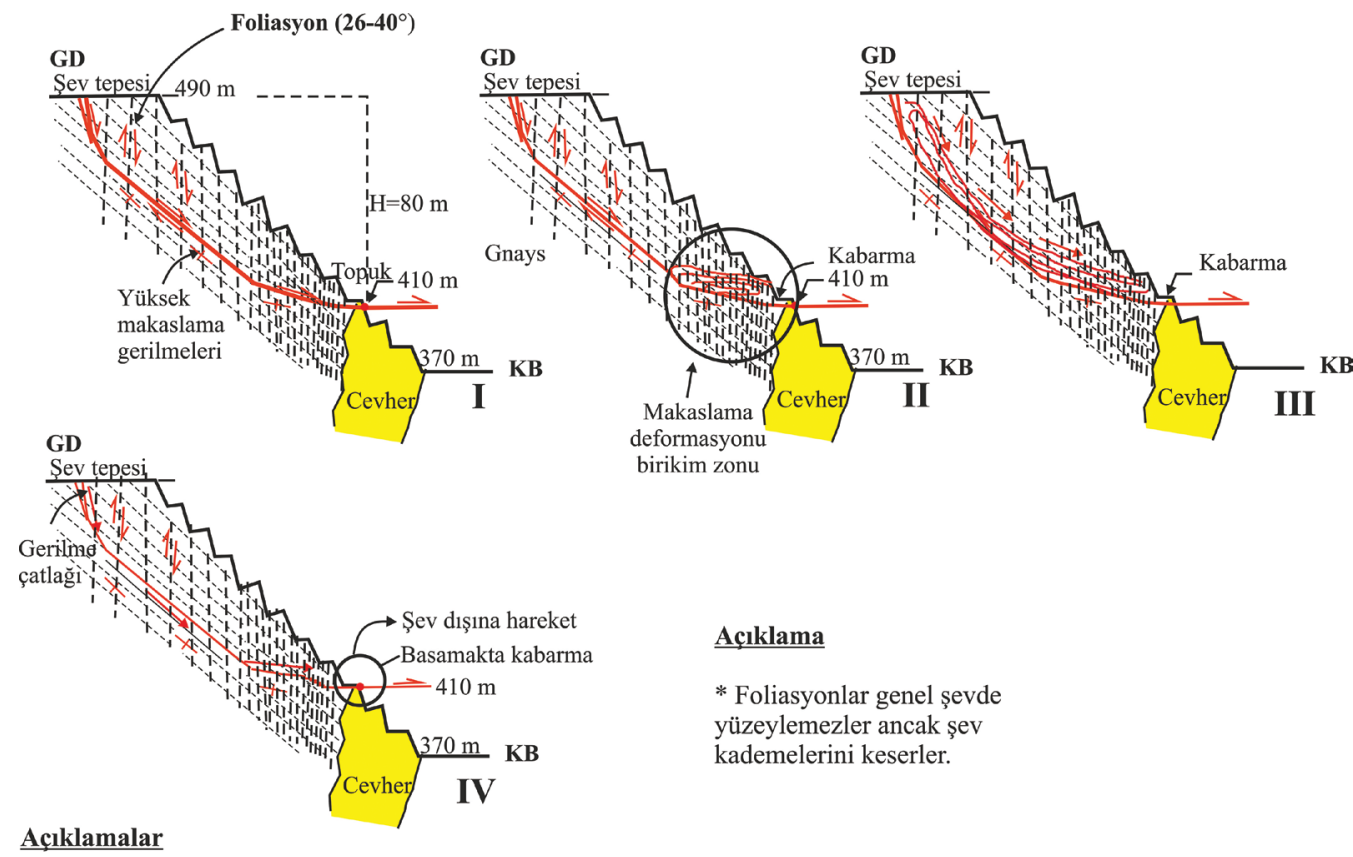

I ve II nolu aşamalar, heyelan başlangıç tepki safhasıdır. I, II ve III nolu aşamalar, heyelan öncesi, IV nolu aşama ise heyelan sonrasına aittir.

—— : Makaslama gerilmesi yüksek, göreceli normal gerilmelerin düşük olduğu zonlar

Şekil 16. Heyelanın öncesinde açık ocak albit madeninde oluşan şev deformasyonlarının aşamaları.

Figure 16. The stages of the slope deformations occurred before the landslide in the open pit albite mine.

10.02.2017'den 20.10.2017'ye dek şev hareketleri bir kez artış göstermiştir. Alınan drenaj önlemleriyle heyelan tehditi ortadan kaldırılmıştır. Geçen yaklaşık sekiz aylık sürede şevde kayda değer deformasyonlar gelişmemiştir. 20.10.2017'den itibaren yağışlarla birlikte deformasyonlar tekrar artış göstermiştir. Yer değiştirmeler artarak 02.11.2018'de kümülatif olarak 1.0 m'ye erişmiştir. 01.01.2018'de ikinci dekapaj çalışması sonucu genel şev açısı artmış ve 2011 yılından sonra ikinci kez gerilme çatlakları şev üst yüzeyinde gelişmiştir. 02 . 11. 2018 'e dek deformasyonların artış nedeni yağışlar ve dekapaj çalışmaları sonrasında oluşan yeni gerilme koşulları olduğu belirlenmiştir.

14.12.2018'den itibaren deformasyonlar maksimum düzeye erişmiş ve şevin yenilmesi kaçınılmaz bir noktaya gelmiştir (Progresif aşama). Bu aşamada, yer değiştirmeler arttıkça şevin stabilitesi kaybolmuş ve yenilme (kırılma) tam olarak gerçekleşmiştir. Gelinen noktada gerilme artmamasına karşın, şev dışına doğru kayma hareketi devam etmektedir. Aynı zaman aralığında yoğun yağışlar ve topuk kazısı, kayma koşulunu oluşturan ikinci parametre olarak belirlenmiştir.

Şev yüzeyine paralel uzanan foliasyonların eğimleri nedeniyle gerilmeleri şev topuğunda arttırdığı ve topukta çatlak gelişiminin yayılmasına neden olduğu anlaşılmıştır. Buna bağlı olarak yenilme modeli, foliasyonlar boyunca kaymayı, foliasyonları yaklaşık dik kesen 82-90/040-070 konumlu çatlak seti ve topukta gelişen s1k çatlaklı zondaki 
makaslamaları kapsamaktadır. Kayma dairesinin zayıf kaya kütlesi özelliğindeki gnaysları kestiği, göreceli yüksek dayanıma sahip cevheri kesmeden, dokanaktan ilerlediği belirlenmiştir.

Potansiyel heyelan sahas1 2014 y1lı saha ölçümlerine göre $62800 \mathrm{~m}^{2}, \quad 19.12 .2018$ 'de gerçekleşen heyelanın ise $21040 \mathrm{~m}^{2}$ olarak ölçülmüştür. Öngörülen ile gerçekleşen arasındaki farkın, dekapaj ve inceltme kazıları sonucu potansiyel heyelan alanının küçülmesi nedeniyle meydana geldiği belirlenmiştir. Heyelanın hareket yönünde herhangi bir farklılık oluşmamıştır.

\section{KAYNAKLAR}

Afeni, T.B., Cawood, F.T., 2013. Slope monitoring using total station: What are the challenges and how should these be mitigated? South African Journal of Geomatics, Vol. 2, No. 1, 41 - 53.

Allasia, P., Manconi, A., Giordan, D. Baldo, M. Lollino, G., 2009. ADVICE: A new pproach for near-real-time monitoring of surface displacements in landslide hazard scenarios. Sensors, 3, 8285-8302.

Bell, R., Glade, T., 2004. Natural hazards and earth system sciences quantitative risk analysis for landslides - Examples from B'1ldudalur, NW Iceland. Natural Hazards and Earth System Sciences, 4, 117-131.

Call, R.D., 1982. Monitoring pit slope behavior, In Proc. 3rd Int. Conf. on Stability in Surface Mining (Vancouver, June $1-3$, pp. $229-248$. New York: Society of Mining Engineers, A. I. M. E.

Call, R.D., Savely, J.P., 1991. Open pit rock mechanics. In SME Mine Engineering Handbook. New York; AIME, pp. $860-882$.

Call, R.D., Cicchini, P.F., Ryan, T.M., Barkley, R.C., 2000. Managing and analyzing overall pit slopes. In Slope Stability in Surface Mining/Edited by William A. Hustrulid, Michael K. McCarter, Dirk, J. A. Van Zyl, Published by the Society for Mining, Metallurgy, and Exploration, Inc. p. 442.

Franklin, J.A., 1977. The monitoring of structures in rock. International Journal of Rock Mechanics and Mining Sciences \& Geomechanics Abstracts, $14,163-192$.
GEOVIA Surpac 6. 6. 1., 2013. GEOVIA Surpac reference manual.

NetCad GIS 7, 2015. NetCad GIS yazilım kullanma kılavuzu.

Karagöz, S.D., Koca, M.Y., 2016. Alipaşa açık ocak albit madeninde meydana gelen heyelanın GPS kullanılarak izlenmesi ve oluşum nedenleri. Jeoloji Mühendisliği Dergisi, 40 (1), s. 27-52.

Kadakçı, K.T., Koca, M.Y., 2014. Açık ocak albit işletmesindeki kaya şevlerinin sonlu elemanlar yöntemi kullanılarak duraylık değerlendirmesi. Jeoloji Mühendisliği Dergisi, 38(1), 1 - 19.

Koca, M.Y., Kahraman, B., Karakuş, D., Özdoğan, M.V., 2010. General assessment of the stability of overall slope of the Alipaşa albite mine. Dokuz Eylül Üniversitesi, 156 s. (unpublished).

Koca, M.Y., Kahraman, B., Kıncal, C., 2012. Report of overall slope stability assessment of the Alipaşa open pit mine. Dokuz Eylül University, 80 s. (unpublished).

Leica Geosystems AG, 2013. Amberg Technologies AG. Ankara. www.sistemas.com.tr. Total Station GRS tm50- Geotechnical E. 541 - 7394/7306/.

MapInfo Professional 8.0, 2000. Software manual.

Martin, D.C., 1993. Time dependent deformation of rock slopes. University of London, $\mathrm{PhD}$ Thesis, London.

Palozzo, D., Friedmann, R., Nadal, C., Santos-Filho, M., Veiga, L., Faggion, P., 2006. Dynamic monitoring of structures using a Robotic Total Station. XXIII FIG Congress, Munich, Germany, Oct. 8-13, 10pp.

Sjöberg, J., 1999. Analysis of large-scale rock slopes. Doctoral thesis 1999: 01, Division of Rock Mechanics, Lule University of Technology.

Simon, L., Valentin, G., Jeffrey, M.Keller, Signer, A., 2012. Monitoring of potentially catastrophic rockslides. CRC Press, London, $101-116$.

Tanyaş, H., Ulusay, R., 2013. Assessment of structurally-controlled slope failure mechanisms and remedial design considerations at a feldspar open pit mine, Western Turkey. Engineering Geology, 155, $54-68$.

Wang J., Gao J., Liu Ch., Wang J., 2010. High precision slope deformation monitoring model based on the GPS/Pseudolites technology in open-pit mine. Mining Science and Technology 20, 0126-0132. 